\title{
Antioxidant and Antivenom Potential of an Essential Oil, 4-(2-Oxo-propyl)-cyclopentane-1,3-dione, and Allantoin Derived from the Polyherbal Combination of Aristolochia indica L. and Piper nigrum L.
}

\author{
Dhivya Sivaraj $\mathbb{D},{ }^{1}$ Ray J. Butcher $\mathbb{D}^{2},{ }^{2}$ Jerry P. Jasinski $\mathbb{D}^{3},{ }^{3}$ Saikumar Sathyanarayanan $\mathbb{D}^{1,4}$ \\ Revathi Ponnusamy $\mathbb{D}^{1},{ }^{1,5}$ Sreeja Puthanpura Sasidharan ${ }^{1}{ }^{1}$ Kasipandi Muniyandi $\mathbb{D}^{1},{ }^{1}$ \\ Parimelazhagan Thangaraj $\mathbb{D}$, 1 and Karuppusamy Arunachalam ${ }^{6}$ \\ ${ }^{1}$ Bioprospecting Laboratory, Department of Botany, Bharathiar University, Coimbatore 641046, Tamil Nadu, India \\ ${ }^{2}$ Inorganic and Structural Chemistry, Howard University, Washington, DC 20059, USA \\ ${ }^{3}$ Physical and Structural Chemistry, Department of Chemistry, Keene State College, 229 Main Street, Keene, \\ NH 03435-2001, USA \\ ${ }^{4}$ Department of Botany, PSG College of Arts and Science (Autonomous), Coimbatore 641014, India \\ ${ }^{5}$ Department of Botany, Kongunadu Arts and Science College (Autonomous), GN Mills, Coimbatore 641029, India \\ ${ }^{6}$ Key Laboratory of Economic Plants and Biotechnology and the Yunnan Key Laboratory for Wild Plant Resources, \\ Kunming Institute of Botany, Chinese Academy of Sciences, Kunming 650201, China
}

\begin{abstract}
Correspondence should be addressed to Parimelazhagan Thangaraj; drparimel@gmail.com and Karuppusamy Arunachalam; arunachalam04@gmail.com
\end{abstract}

Received 17 January 2022; Accepted 16 February 2022; Published 7 March 2022

Academic Editor: Vijaya Anand

Copyright (C) 2022 Dhivya Sivaraj et al. This is an open access article distributed under the Creative Commons Attribution License, which permits unrestricted use, distribution, and reproduction in any medium, provided the original work is properly cited.

The goal of this study was to identify new compounds from a methanol extract of a polyherbal combination of Aristolochia indica L. and Piper nigrum L. (MECAIPN), two traditional medicinal plants used to cure envenomation, as well as to assess their antioxidant and antivenom properties. MECAIPN yielded EA1 (an essential oil), AA2 (4-(2-oxo-propyl)-cyclopentane-1,3dione), and W3 ((2,5-dioxo-imidazolidin-4-yl)-urea) (Allantoin). Although EA1 had stronger radical scavenging activity, AA2 had higher DPPH and ferric ion radical scavenging activity, and W3 had higher molybdenum ion radical scavenging activity due to being a single molecule, the binding investigation revealed that EA1 has a greater Stern-Volmer quenching constant (Ksv) than AA2 and W3. Synchronous measurements indicated that EA1, AA2, and W3 bind to tryptophan and tyrosine residues in venom, causing denaturation of the secondary structure of the residue. Finally, the current study concludes that EA1 has more therapeutic antivenom potential, which could be related to the synergism of chemicals found in it. When it came to single compounds, AA2 had stronger antioxidant and antivenom capabilities than W3. To understand the mechanism of action and manufacture the green antivenom medication, more testing of the EA1 and compounds remains required.

\section{Introduction}

The genus "Scolopendra" is a venomous terrestrial arthropod whose envenomation has a negative impact on human health due to hypersensitivity. Pain, giddiness, sudden myocardial infarction, and skin-related disorders such as itching, erythema, blemishes, necrosis, aureole, and wound development are all symptoms of hypersensitive reactions. Metalloproteases, hyaluronidase, and phospholipase A2 are among the enzymes in the venom, as are CAP protein, ion channel modulators, cardiotoxin, myotoxin, and cytotoxin, among others. Envenomation also induces oxidative stress by promoting the production of damaging free radicals and damaging macromolecules (lipids, proteins, and nucleic 
acids). Many illnesses, including as inflammation, cancer, metabolic problems, and aging, are caused by changes in macromolecule structure and function [1]. The medicinal plant is used in the Indian traditional medical systems "Ayurveda and Siddha," which has the capacity to heal lifethreatening disorders. Both systems favor "polyherbal formulation" over uniherbal medication to gain additional therapeutic efficiency through the synergism process $[2,3]$. Oraon tribes of Latehar district, Jharkhand, employ the medicinal plants $A$. indica (root) and P. nigrum (seed) to cure envenomation $[1,4]$. The Malayali tribes of the Yercaud hills ingest $A$. indica root orally for 1 week to cure centipede envenomation [5]. Chittoor district (Andhra Pradesh) uses $P$. nigrum seeds to cure toxic bites [6]. In this regard, a previous study (published in Journal of Biomedicine and Pharmacotherapy) found that a methanol extract of a combination of $A$. indica and $P$. nigrum (MECAIPN) was more effective than individual plant extracts and the standard drug "Medrol" against Scolopendra morsitans L. envenomation effects [1]. As a result, the current study aims to isolate new compounds from MECAIPN and assess their antioxidant and antivenom properties.

\section{Materials and Methods}

2.1. Chemicals. The solvents used are as follows: methanol, dimethyl sulfoxide (DMSO), chloroform, ethyl acetate, acetic acid, and water, as well as 2,2-diphenyl-1-picrylhydrazyl (DPPH), silica gel, phosphate buffer, ascorbic acid, 2,4,6-tri(2-pyridyl)-s-triazine (TPTZ), ferrous sulphate, and butylated hydroxyltoluene (BHA). Analytical-grade chemicals and solvents were employed throughout.

2.2. Extraction. Botanical Survey of India (BSI), Coimbatore, Tamil Nadu, validated the taxonomic identification of A. indica (root bark) and P. nigrum (seed), which were collected during the month of June (early morning $7.30 \mathrm{am}$ ) at Dharapuram (GPS, coordinates: $10^{\circ} 43^{\prime} 58.566^{\prime \prime} \mathrm{N}$ and $77^{\circ}$ $31^{\prime} 18.5268^{\prime \prime} \mathrm{E}$ ) and Ooty (coordinates: $11.4102^{\circ} \mathrm{N}$ and $17.6950^{\circ} \mathrm{E}$ ), Tamil Nadu, India (BSI/SRC/5/23/2014-15/ Tech.1253 and 1457, respectively). Both powders (CAIPN) were combined in a $1: 1$ ratio $(100 \mathrm{~g})$ and extracted for $60 \mathrm{~h}$ with Soxhlet at $65^{\circ} \mathrm{C}$ and $400 \mathrm{~mL}$ of methanol. The extract was then concentrated using a rotary vacuum evaporator (Equitron, India) to eliminate the rest of the solvent, and thereafter the extract was air-dried, weighed, and stored in desiccators.

2.3. Collection of Venom. Scolopendra morsitans was collected in July, Dharapuram district, Tamil Nadu, India, and recognized as S. morsitans L. by the Zoological Survey of India (ZSI), Kerala (Reg. no. ZSI/WGRC/IR/INV/ 4152). The centipedes were kept in containers with air holes, soil, and litter items to keep them alive. Spraying water on the soil kept the moisture content up. The termites were offered as a source of nutrition. Venom was collected by activating the venom glands with an electrical device that had a frequency of $128 \mathrm{~Hz}$, a voltage of 10 to
$20 \mathrm{~V}$, and a pulse width of 2 to $4 \mathrm{~ms}$. Each milking occurred 2 weeks after the previous milking. The collected venom was stored at $-20^{\circ} \mathrm{C}[7]$.

2.4. Column Chromatography and Characterization. Based on earlier research, MECAIPN was chosen for chemical isolation. MECAIPN (50 g) was adsorbed on activated silica (60-120 mesh) while the methanol was continuously stirred. The column $(59 \times 4.5 \mathrm{~cm})$ was packed with activated silica gel (60-120 mesh) in petroleum ether (stationary phase) using the wet packing method, and it was eluted with $600 \mathrm{~mL}$ of mobile phase containing various solvents such as petroleum ether (100\%), petroleum ether (A): chloroform (B) (5-100\%), chloroform (A): ethyl acetate (B) (5-100\%), ethyl acetate (A): methanol (B) (5-100\%) [in order to improve the polarity of the mobile phase, the concentration of " $\mathrm{A}$ " was reduced from $95,90,85$, and 80 to $0 \%$, and the concentration of " $\mathrm{B}$ " was raised by $5,10,15,20$, 25 up to $100 \%$ ], acetic acid (1 and $2 \%$ in distilled water), and distilled water $(100 \%)$. The elution volume was $10 \mathrm{~mL}$ and the flow rate was $3 \mathrm{~mL} / \mathrm{min}$. On a precoated silica gel $60 \mathrm{~F} 254$ TLC (Thin layer chromatography) plate, TLC profiling was performed (Merck, Germany). In a saturated chromatographic chamber, the chromatogram was created. The produced plate was examined in an ultraviolet (UV) and iodine chamber. The formula $\left(R_{f}=\right.$ distance travelled by the solute/distance travelled by the solvent) was used to get the $R_{f}$ value of the location. The elution fractions with comparable chemical signatures were grouped together based on TLC findings. From the 4:6 (ethyl acetate: methanol) elution, the oil EA1 $(4 \mathrm{~mL})$ was recovered. From $1 \%$ acetic acid in water and $100 \%$ water, the colorless crystals AA2 $(4.65 \mathrm{~g})$ (water:methanol:acetic acid in $8: 1: 1 ; R_{f}: 0.85$ ) and W3 $(1.32 \mathrm{~g})$ (water : acetic acid in $\left.9.9: 0.1 ; R_{f}: 0.11\right)$ were produced [8].

2.5. Determination of Free Fatty Acid Content and an Acid Value of EA1. One milliliter of EA1 was combined with a neutral solvent $(25 \mathrm{~mL}$ ether, $25 \mathrm{~mL} 95 \%$ ethanol, and $1 \%$ phenolphthalein solution) and titrated against $0.1 \mathrm{~N}$ potassium hydroxide for $15 \mathrm{sec}$ until the pink color remained persistent. Using equation (1) $\mathrm{mL} \mathrm{N} / 10 \mathrm{KOH}$ (potassium hydroxide $)=0.028 \mathrm{~g}$ oleic acid, the free fatty acid was estimated as oleic acid [9The acid value is calculated using the formula, Acid value $(\mathrm{mg} \mathrm{KOH} / \mathrm{mL})=\mathrm{T} \times \mathrm{N} \times \mathrm{MW} /$ Volume of EA $1(\mathrm{~mL})$ Where, $\mathrm{T}=$ Titre value, $\mathrm{N}=$ Normality of $\mathrm{KOH}$, and $\mathrm{MW}=$ Molecular weight of $\mathrm{KOH}$.

2.6. Determination of Saponification Value of EA1. In a flask, $2 \mathrm{~mL}$ of EA1 was weighed. The alcoholic $\mathrm{KOH}(25 \mathrm{~mL})$ was pipetted into the mixture and allowed to drain for approximately $1 \mathrm{~min}$. A blank determination was made and measured at the same time as the sample. For full saponification, a condenser was attached to the flask, and the combined sample was allowed to boil gently and continuously for $45 \mathrm{~min}$. Thereafter the flask and condenser were cooled, but not enough to form a gel. After disconnecting the 
condenser, $1 \mathrm{~mL}$ of phenolphthalein indicator was added to the flask's contents. With 0.5 N HCL (hydrogen chloride), the solution was titrated until the pink color faded completely [10]. Saponification value was determined using the formula saponification value $=(B-S) \times 56.1 \times N /$ weight of EA1 (g), where $B$ is the blank titre value, $S$ is the sample titre value, and $N$ is the HCL normality.

2.7. Determination of Molecular Weight of EA1. From saponification and an acid value, the molecular weight [11] of EA1 was determined as MW $=168300 / \mathrm{SV}$ AV, where MW represents the oil's molecular weight, SV represents the saponification value, and AV represents the acid value.

2.8. Gas Chromatography-Mass Spectrum (GC-MS) Analysis of EA1. Shimadzu GC-MS, QP2010S, was used for the GCMS analysis. Compound separations were carried out on an Rxi-5Sil MS column with a length of $30 \mathrm{~m}$, a diameter of $0.25 \mathrm{~mm}$, and a thickness of $0.25 \mu \mathrm{m}$. The chromatographic and mass spectrometric data were processed using GC-MS Solutions software. The temperature in the GC oven was kept at $700^{\circ} \mathrm{C}$ for $5 \mathrm{~min}$, then steadily increased to $2900^{\circ} \mathrm{C} \mathrm{min}^{-1}$ at a rate of $50^{\circ} \mathrm{C} \mathrm{min}{ }^{-1}$ for another $5 \mathrm{~min}$. The oil sample was divided at a 1:16 splitting ratio and injected in the split mode. As a carrier gas, helium was employed at a constant flow rate of $1 \mathrm{~mL} \mathrm{~min}^{-1}$. The electron impact mode of the mass selective detector was used, with an electron energy of $70 \mathrm{eV}$. The obtained GC-MS profile was examined by comparing the chromatogram to commercially available standards using the NIST (National Institute of Standards and Technology) 11 and WILEY 8 libraries [12].

2.9. Fourier Transform Infrared Spectroscopy (FT-IR) Analysis. To make transparent sample discs, EA1 $(0.5 \mathrm{~mL})$ and $10 \mathrm{mg}$ of AA2 and W3 crystal powder were encapsulated in $100 \mathrm{mg}$ of $\mathrm{KBr}$ pellet. To identify the distinctive peaks and their functional groups, the powdered sample was put into an FT-IR (Fourier transform infrared) spectroscopy (Perkin Elmer Spectrum GX) in the (4000-400) $\mathrm{cm}^{-1}$ range. The FTpeak IR's values were recorded. For spectrum confirmation, the procedure was done twice [13].

2.10. Nuclear Magnetic Resonance Spectroscopy (NMR). The signal processing information base was used to determine the ${ }^{1} \mathrm{H}-\mathrm{NMR}$ and ${ }^{13} \mathrm{C}-\mathrm{NMR}$ spectra. At room temperature, ${ }^{1} \mathrm{H}(-2-15 \mathrm{ppm})$ and ${ }^{13} \mathrm{C}(0-220 \mathrm{ppm}) \mathrm{NMR}$ were recorded on a Bruker DPX 400 spectrometer (ppm, $J$ in $\mathrm{Hz}$ ) running at $400 \mathrm{MHz}{ }^{1} \mathrm{H}(-2-15 \mathrm{ppm})$ and ${ }^{13} \mathrm{C}(0-220 \mathrm{ppm})$. Chemical changes were measured in parts per million (ppm). The internal standard was tetramethylsilane (TMS). Ten milligrams of compounds were dissolved in a maximum of $2 \mathrm{~mL}$ of DMSO, which was chosen as the solvent of choice due to the compounds' solubility. Clean Pasteur pipettes were used to pipette the impurity-free solutions into NMR tubes for examination.
2.11. Energy Dispersive X-Ray Analysis (EDX). The EDX was used to determine the elemental makeup of the AA2 and W3 (Brukers). Gold sputtering was used to cover the compounds prior to analysis. Low electron energies of $1 \mathrm{keV}$ to $10 \mathrm{keV}$ were used to capture secondary electron pictures.

2.12. Single-Crystal X-Ray Diffraction Analysis (Sc-XRD). The X-ray crystallographic investigation was performed on a clear vivid white columnar-like specimen with approximate dimensions of $0.165 \mathrm{~mm} \times 0.201 \mathrm{~mm} \times 0.365 \mathrm{~mm}$ (AA2). The $\mathrm{X}$-ray intensity measurements were collected in a Bruker D8 Quest over a 3:04-h room temperature exposure. A narrowframe method was used to merge the frames using the Bruker Saint Software package. The multi-scan approach was used to adjust for absorption effects in the data (SADABS). The solvent Apex II program was used to solve the structure. Table 1 shows the data gathering and refining procedure for AA2. For the X-ray crystallographic study, a clear bright white columnar-like specimen with approximate dimensions of $0.558 \times 0.168 \times 0.030 \mathrm{~mm}^{3}$ (W3) was placed on a Mitgencryoloop in random orientation (Bruker AXS SMART APEX CCD). Table 2 shows the specifics of W3's data collecting and refining procedures.

\subsection{In Vitro Antioxidant Assay}

2.13.1. $\mathrm{DPPH}^{\bullet}$ Scavenging Activity. Approximately $3 \mathrm{~mL}$ of $0.1 \mathrm{mM}$ methanolic DPPH solution was added to the aliquots of the samples and standards (BHT) and vigorously shaken. The negative control was made by mixing $100 \mu \mathrm{L}$ methanol with $3 \mathrm{~mL}$ of $0.1 \mathrm{mM}$ DPPH methanol solution. At $27^{\circ} \mathrm{C}$, the tubes were left to stand for $30 \mathrm{~min}$. The sample's absorbance was measured at $517 \mathrm{~nm}$ and represented as an $\mathrm{IC}_{50}$, which was the sample concentration necessary to inhibit $50 \%$ of DPPH concentration [8].

2.13.2. Ferric Reducing Antioxidant Power Assay. A quantity of $2.5 \mathrm{~mL}$ of $10 \mathrm{mM}$ TPTZ in $40 \mathrm{mM} \mathrm{HCL}, 2.5 \mathrm{~mL}$ of $20 \mathrm{mM}$ $\mathrm{FeCl}_{3} \cdot 6 \mathrm{H}_{2} \mathrm{O}$, and $25 \mathrm{~mL}$ of $0.3 \mathrm{M}$ acetate buffer were combined to make the FRAP reagent ( $\mathrm{pH}$ 3.6). The FRAP reagent $(900 \mu \mathrm{L})$ was combined with $270 \mu \mathrm{L}$ of distilled water and $100 \mu \mathrm{L}$ of test material after being newly produced and incubated at $37^{\circ} \mathrm{C}$. The test sample was diluted to $1 / 34$ in the reaction mixture at the end. In a water bath, the test samples and reagent blank were incubated for $30 \mathrm{~min}$ at $37^{\circ} \mathrm{C}$. A spectrophotometer was used to measure the absorbance at $593 \mathrm{~nm}$ against the reagent blank at the conclusion of the incubation. As a baseline, BHT was employed. For the calculations, a methanolic solution with known $\mathrm{Fe}(\mathrm{II})$ concentrations ranging from 500 to $4000 \mathrm{mM}$ $\left(\mathrm{FeSO}_{4} \cdot 7 \mathrm{H}_{2} \mathrm{O}\right)$ was used. The equivalent concentration was estimated as the antioxidant concentration that increased the absorbance in the FRAP experiment to the predicted absorbance value of $1 \mathrm{mM} \mathrm{Fe}(\mathrm{II})$ solution [8].

2.13.3. Phosphomolybdenum Activity. In a test tube, triplicates of $100 \mu \mathrm{L}$ of samples were mixed with $3 \mathrm{~mL}$ of reagent solution ( $0.6 \mathrm{M}$ sulphuric acid, $28 \mathrm{mM}$ sodium phosphate, 
TABLE 1: Data collection and refinement program of compound AA2.

\begin{tabular}{|c|c|}
\hline Theta range for data collection & 2.76 to $27.12^{\circ}$ \\
\hline Index ranges & $-10 \leq h \leq 10,-6 \leq k \leq 6,-17 \leq 1 \leq 19$ \\
\hline Reflections collected & 8399 \\
\hline Wavelength & $0.71073 \AA$ \\
\hline Independent reflections & $1355[R$ (int) $=0.0660]$ \\
\hline Coverage of independent reflections & $99.9 \%$ \\
\hline Absorption correction & Multi-scan \\
\hline Max. and min. transmission & 0.9790 and 0.9550 \\
\hline Refinement method & Full-matrix least-squares on $F^{2}$ \\
\hline Refinement program & SHELXL-2014/7 (Sheldrick, 2014) \\
\hline Function minimized & $\sum w\left(F_{o}^{2}-F_{c}^{2}\right)^{2}$ \\
\hline Data/restraints/parameters & $1355 / 0 / 101$ \\
\hline Goodness-of-fit on $F^{2}$ & 1.080 \\
\hline Final $R$ indices & $\begin{aligned} R 1 & =0.0810, w R 2=0.2477 \\
R 1 & =0.0923, w R 2=0.2612\end{aligned}$ \\
\hline Weighting scheme & $w=1 /\left[\sigma^{2}\left(F_{o}^{2}\right)+(0.1402 P)^{2}+1.5335 P\right]$, where $P=\left(F_{o}^{2}+2 F_{c}^{2}\right) / 3$ \\
\hline Extinction coefficient & $0.0800(200)$ \\
\hline Largest diff. peak and hole & 0.638 and $-0.380 \mathrm{e}^{-3}$ \\
\hline R.M.S. deviation from mean & $0.113 \mathrm{e}^{-3}$ \\
\hline
\end{tabular}

TABLE 2: Data collection and refinement program of compound W3.

\begin{tabular}{lc}
\hline Theta range for data collection & 5.518 to $71.202^{\circ}$. \\
\hline Index ranges & $-9 \leq h \leq 9,-6 \leq k \leq 5,-13 \leq 1 \leq 17$ \\
Reflections collected & 1943 \\
Independent reflections & $1153[R$ (int) $=0.0181]$ \\
Completeness to theta $=67.684^{\circ}$ & $99.5 \%$ \\
Wavelength & $1.54184 \AA$ \\
Absorption correction & Analytical \\
Max. and min. transmission & 0.922 and 0.495 \\
Refinement method & Full-matrix least-squares on $F^{2}$ \\
Refinement program & SHELXL-2014/7 (sheldrick, 2014) \\
Data/restraints/parameters & $1355 / 0 / 101$ \\
Goodness-of-fit on $F^{2}$ & 1.046 \\
Final $R$ indices & all data \\
Weighting scheme & $w=1 /\left[\sigma^{2}\left(F_{o}{ }^{2}\right)+(0.1402 P)^{2}+1.5335 P\right]$ where $P=\left(F_{o}{ }^{2}+2 F_{c}^{2}\right) / 3$ \\
Extinction coefficient & $0.0800(200)$ \\
Largest diff. peak and hole & 0.229 and $-0.208 \AA^{-3}$ \\
\hline
\end{tabular}

and $4 \mathrm{mM}$ ammonium molybdate) and varied quantities of standard (ascorbic acid in $1 \mathrm{mM}$ dimethyl sulphoxide). The test tubes were incubated for $90 \mathrm{~min}$ in a water bath at $95^{\circ} \mathrm{C}$. The absorbance of the combination was measured at $695 \mathrm{~nm}$ against the reagent blank after the samples had cooled to room temperature. A typical blank solution had $3 \mathrm{~mL}$ of reagent solution and water in the place of the sample, and it was incubated at the same temperature as the other samples. As a control, the synthetic antioxidant BHT was utilized. The findings were given as mean values in $\mathrm{mg}$ of ascorbic acid equivalents (AAE) per gram of the sample [8].

2.14. Venom Protein Binding Studies. The venom was dissolved in phosphate buffer $(\mu \mathrm{L} / \mathrm{mL})(\mathrm{pH} 7.2)$. For the venom protein binding investigation, the excitation wavelength of venom was measured at $280 \mathrm{~nm}$ and the emission wavelength was measured at $346 \mathrm{~nm}$. For all of the trials, the excitation and emission slit widths and scan speeds were kept constant. For all of the studies, a concentrated stock solution of the samples was generated by dissolving the relevant materials in DMSO, phosphate buffer, and diluting appropriately with deionized water to the needed concentrations (percentage of DMSO (v/v) in the final solution). Titrations were carried out manually with the addition of the samples $(10-100 \mu \mathrm{M})$ using a micropipette. The same concentration of venom and samples was utilized for synchronous fluorescence spectra, and the spectra were taken at two distinct $\Delta \lambda$ values (difference between the excitation and emission wavelengths of venom), such as 15 and $60 \mathrm{~nm}$. A $1 \mathrm{~cm}$ quartz cell on a JASCO FP 6600 spectrofluorimeter [14] was used for fluorescence and synchronous measurements.

The quenching ability was evaluated by the Stern-Volmer equation:

$$
\frac{I_{o}}{I_{\text {corr }}}=K_{\mathrm{SV}}[Q]+1,
$$

where $I_{o}$ is the emission intensity in the absence of samples, $I_{\text {corr }}$ is the corrected emission intensity in the presence of the 
sample, $K_{\mathrm{sv}}$ is the quenching constant, and $[Q]$ is the concentration of the sample.

In order to correct the inner filter effect, the following equation is used [15]:

$$
I_{\text {corr }}=I_{\text {obs }} * 10^{\left(A_{\text {exc }}+A_{\text {em }}\right) / 2} \text {, }
$$

where $I_{\text {corr }}$ is the corrected fluorescence value, $I_{\text {obs }}$ is the measured fluorescence value, $A_{\text {exc }}$ is the absorption value at the excitation wavelength, and $A_{\mathrm{em}}$ is the absorption value at the emission wavelength. The binding constant $\left(K_{b}\right)$ and the number of binding sites $(n)$ may be calculated using the static quenching interaction, assuming comparable and independent binding sites are considered in the biomolecule [16]. The Scatchard equation may be used to solve this problem, which is as follows:

$$
\log \left[\frac{\left.F_{o}-F\right)}{F}\right]=\log K_{b}+n \log [Q] .
$$

The number of binding sites per molecule (venom) can be determined by the slope and intercept of a double logarithm regression curve of $\left.\log \left[F_{o}-F\right) / F\right]$ versus $\log [Q]$, where $K_{b}$ is the binding constant for the compound-venom protein interaction and " $n$ " is the number of binding sites per molecule (venom). At room temperature, the values of " $n$ " are roughly equal to 1 , indicating that there was just one binding site in the venom for the samples.

2.15. Statistical Analysis. Data expressed as mean \pm standard deviation were statistically analyzed using SPSS 20.0 by means of one-way ANOVA followed by Duncan's test, significant when $p<0.05$.

\section{Results}

The amount of free fatty acids in the essential oil (EA1) was $43.1 \pm 20.18 \%$ oleic acid equivalents/g. EA1 has acid and saponification values of $17.28 \pm 0.18 \mathrm{mg} \mathrm{KOH} / \mathrm{mL}$ and $189.3 \mathrm{mg}$ $\mathrm{KOH} / \mathrm{mL}$, respectively. EA1 has an average molecular weight of 978.37 . FT-IR spectrum showed the presence of functional groups like $\mathrm{O}-\mathrm{H}\left(3816.44,3668.91\right.$, and $\left.3200.29 \mathrm{~cm}^{-1}\right), \mathrm{C}-\mathrm{H}$ (3060.48, 1608.34, and $\left.1184.08 \mathrm{~cm}^{-1}\right)$, and C-O (2355.62, 2202.31, and $1779.97 \mathrm{~cm}^{-1}$ ) (Figure 1(a)). The existence of 63 compounds was discovered using GC-MS (Table 3), and their GC chromatogram is shown in Figure 1(b). Six were the major compounds and they are 1, 5, 5-trimethyl-6-(3-methylbuta-1,3-dienyl)-cyclohexene (27.74\% and RT: 23.498), 1heneicosanol (4.91\% and RT: 31.760$)$, ledol (4.29\% and RT: 20.072), E-15-heptadecenol (4.12\% and RT: 25.265), heptadecane (3.30\% and RT: 17.542), and phenol, 2,4,-bis(1,1, dimethyl ethyl) (3.06\% and RT: 19.821)

The presence of functional groups such as $\mathrm{O}-\mathrm{H}$ $\left(3776.62 \mathrm{~cm}^{-1}\right), \mathrm{H}-\mathrm{C}=\mathrm{O}: \mathrm{C}-\mathrm{H}\left(2358.94\right.$ and $\left.2856.58 \mathrm{~cm}^{-1}\right)$, and $\mathrm{C}-\mathrm{H}\left(1454.33\right.$ and $\left.1371.39 \mathrm{~cm}^{-1}\right)$ could be seen in the absorption bands of the FT-IR spectrum (Figure 2(a)). Peaks corresponding to the chemical shift were found at $10.547 \mathrm{ppm}(\mathrm{H}) ; 8.065 \mathrm{ppm}(\mathrm{C}=\mathrm{C}-\mathrm{H}) ; 6.906$ and $6.886 \mathrm{ppm}$ $(\mathrm{H}-\mathrm{C}=\mathrm{C}-)$; and $5.796,5.260$, and $5.29 \mathrm{ppm}(\mathrm{C}-\mathrm{OH})$ on the
${ }^{1} \mathrm{H}$-NMR spectrum (Figure 2(b)). Peaks were found at chemical shifts of $174.05 \mathrm{ppm}\left(\mathrm{CH}\right.$ and $\left.\mathrm{CH}_{2}\right) ; 157.41$ and $157.21 \mathrm{ppm}(\mathrm{C}=\mathrm{C})$; and $62.03 \mathrm{ppm}$ (Figure 2(c)) $\left(\mathrm{CH}_{2}\right)$. In the compound AA2, EDX examination revealed the existence of components such as carbon $(\mathrm{C})$ and oxygen $(\mathrm{O})$ (Figure 2(d)). Tables 4 and 5 exhibit Sc-XRD data for the specified bond lengths and orientations of the compound AA2. This chemical crystallized in the P $121 / c 1$ monoclinic space group. Table 6 shows the atomic coordinates and corresponding isotropic atomic displacement parameters $\left(\AA^{2}\right)$ of compound AA2. Table 7 lists the torsion angles $\left({ }^{\circ}\right)$, whereas Tables 8 and 9 provide the anisotropic atomic displacement parameters $\left(\AA^{2}\right)$ and hydrogen atomic coordinates and isotropic atomic displacement parameters $\left(\AA^{2}\right)$. The molecular structure of the chemical AA2 was determined using these data. The molecule was identified as 4-(2oxo-propyl)-cyclopentane-1,3-dione using the Chem Draw Ultra program 7.0.1 version and its molecular formula is $\mathrm{C}_{8} \mathrm{H}_{6} \mathrm{O}_{3}$ (Molecular weight: $150.13 \mathrm{~g} / \mathrm{mol}$ ). Its chemical structure is depicted in Figure 2(e). The compound AA2 was assigned the number 1574042 by the Cambridge Crystallographic Data Centre (CCDC).

W3 absorption bands in the FT-IR spectrum are shown in Figure 3(a). O-H $\left(3438.46\right.$ and $\left.3345.89 \mathrm{~cm}^{-1}\right), \mathrm{C}=\mathrm{O}$ $\left(1716.34,1780.94\right.$, and $\left.1659.45 \mathrm{~cm}^{-1}\right), \mathrm{N}-\mathrm{H}\left(1659.45 \mathrm{~cm}^{-1}\right)$, $\mathrm{C}-\mathrm{H}\left(1530.24 \mathrm{~cm}^{-1}\right)$, and $\mathrm{O}=\mathrm{C}-\mathrm{H}\left(2764.46 \mathrm{~cm}^{-1}\right)$ were all found. The ${ }^{1} \mathrm{H}$-NMR and ${ }^{13} \mathrm{C}$-NMR of $\mathrm{W} 3$ are shown in Figure 3(b) and 3(c). Peaks at chemical shifts of 8.06, 6.90, 5.79 , and $5.25 \mathrm{ppm}$ indicate the presence of $(\mathrm{N}-\mathrm{H})$ groups, whereas the peak at $3.35 \mathrm{ppm}$ shows the presence of $(\mathrm{C}-\mathrm{H})$ groups. Peaks corresponding to chemical shifts at 173.60 , $157.35,156.76$, and $62.41 \mathrm{ppm}$ were found by ${ }^{13} \mathrm{C}-\mathrm{NMR}$, indicating the existence of four carbons. The molecule W3 has carbon $(\mathrm{C})$, nitrogen $(\mathrm{N})$, and oxygen $(\mathrm{O})$ in its EDX spectra (Figure 3(d)). Tables 10 and 11 provide Sc-XRD data for the specified bond length and bond angles of compound W3. The chemical W3 formed monoclinic space group P 21/ c crystals. Table 12 shows the distance between hydrogen acceptor and donor, whereas Figure 3(e) shows hydrogen bonding. The atomic coordinates $\left(\times 10^{4}\right)$ and comparable isotropic displacement parameters $\left(\AA^{2} \times 10^{3}\right)$ described in Tables 13-15 show anisotropic displacement parameters $\left(\AA^{2} \times 10^{3}\right)$ and hydrogen coordinates $\left(\times 10^{4}\right)$, as well as isotropic displacement parameters $\left(\AA^{2} \times 10^{3}\right)$. Table 16 shows the torsional angles $\left({ }^{\circ}\right)$ of W3. W3's chemical formula was predicted using these data as $\mathrm{C}_{4} \mathrm{H}_{6} \mathrm{~N}_{4} \mathrm{O}_{3}$ (molecular weight: $158.13 \mathrm{~g} / \mathrm{mol}$ ). Figure $3(\mathrm{f})$ depicts the chemical structure of W3 as predicted by Chem Draw Ultra software 7.0.1 version as (2,5-dioxo-imidazolidin-4-yl)-urea. Compound W3 has a CCDC number of 1574043.

The radical scavenging activity of EA1 was greater than that of AA2 and W3 for DPPH $\left(\mathrm{IC}_{50}=23.17 \mu \mathrm{g} / \mathrm{mL}\right)$, ferric (23303.57 $\pm 68.53 \mathrm{Fe}(\mathrm{II}) \mathrm{E} / \mathrm{g}$ of the sample), and molybdenum $(709.17 \pm 1.51 \mathrm{mg} \mathrm{AAE} / \mathrm{g}$ of the sample) (Table 17). When compared to EA1, the synthetic antioxidant BHT had stronger radical scavenging activity. However, when it came to single compounds, AA2 was better at scavenging DPPH and ferric ions radicals, whereas W3 was better at scavenging molybdenum radicals. 


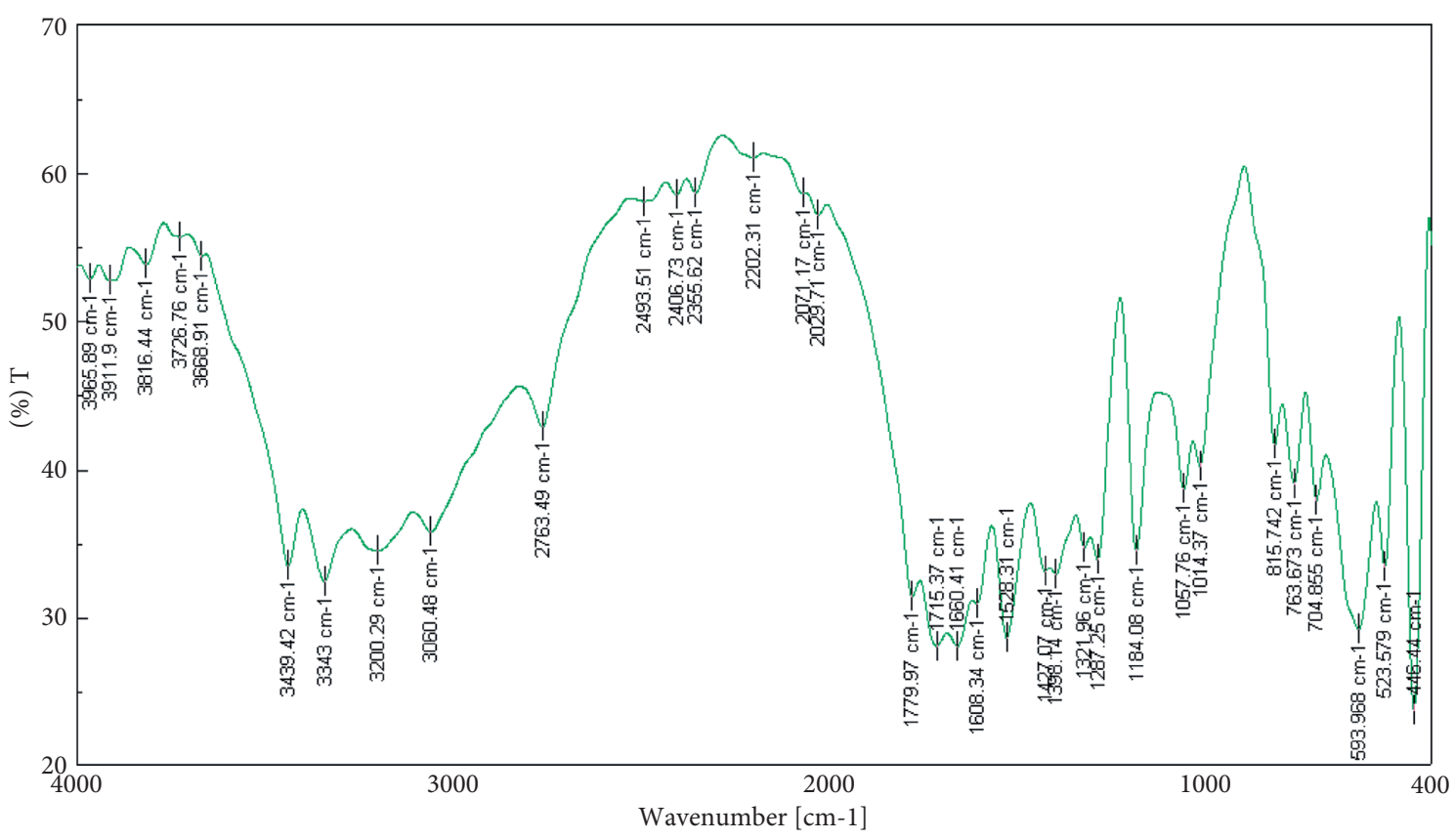

(a)

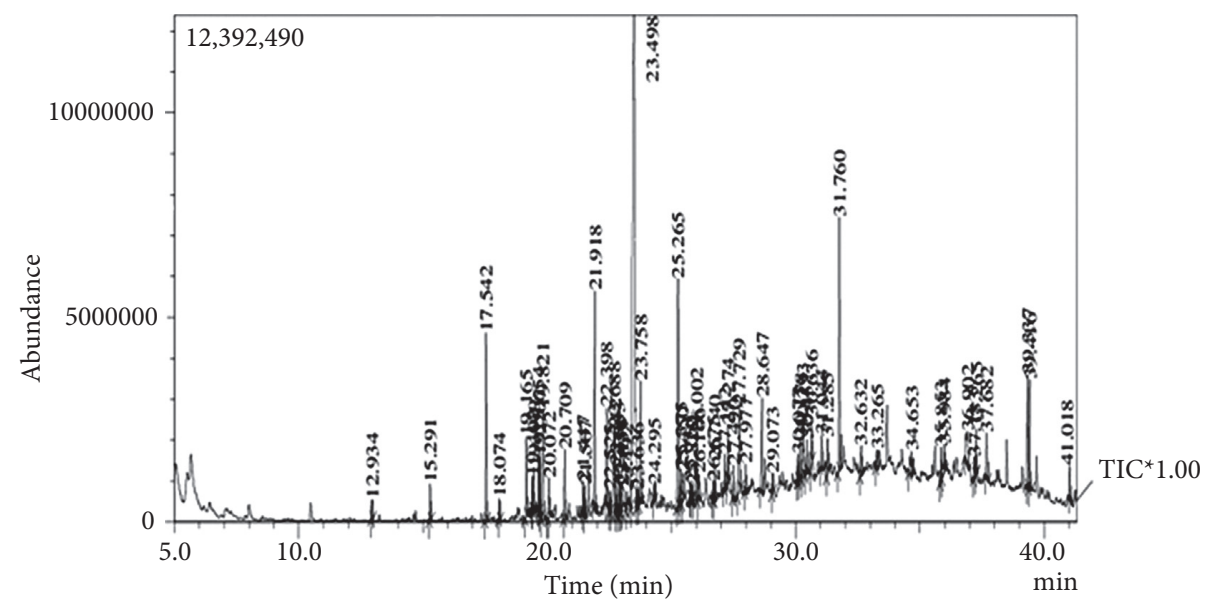

(b)

Figure 1: (a) FT-IR spectrum of EA1. (b) GC chromatogram of EA1.

The changes observed on the emission spectra of $\mathrm{S}$. morsitans venom as a result of the addition of increasing concentration of EA1, AA2, and W3 samples (Figures 4(a)$4(c))$. The fluorescence intensity of venom at $340 \mathrm{~nm}$, $340 \mathrm{~nm}$, and $341 \mathrm{~nm}$ decreased by $37.1 \%, 29.2 \%$, and $95.5 \%$ for the samples AA2, W3, and EA1, respectively, with blueshifts of $1 \mathrm{~nm}, 1 \mathrm{~nm}$, and redshifts of $4 \mathrm{~nm}$. The quenching constant $K_{\mathrm{sv}}$ calculated from the plot of $I_{o} / I$ against $[Q]$ was determined to be $4.780 .054104 \mathrm{M}^{-1}, 4.11$ $0.054104 \mathrm{M}^{-1}$, and $9.990 .123105 \mathrm{M}^{-1}$, respectively, according to the Stern-Volmer quenching equation. The capacity of the materials to quench the emission intensity of venom was demonstrated by the linearity obtained in the Stern-Volmer plots of Figure 5 and Table 18. The Scatchard plot (Figure 6) was used to calculate the binding constant $\left(K_{\text {bin }}\right)$ and the number of binding sites $(n)$, and the findings are provided in Table 18. EA1 had a higher binding constant $\left(9.52 \pm 0.0810^{6}\right)$ and a larger number of binding site factor (1.479) than both AA2 and W3. There was a drop in the emission intensity of the venom corresponding to tyrosine and tryptophan residues with a red shift after adding the samples (Figures 7(a)-7(c) and 8(a)-8(c)). 4-(2-Oxo-propyl)-cyclopentane-1,3-dione, on the other hand, had higher potential in reducing the intensity of venom emission than (2,5-Dioxo-imidazolidin-4-yl)-urea as a single chemical.

\section{Discussion}

An essential oil, and two colorless crystal compounds such as AA2-4-(2-oxo-propyl)-cyclopentane-1,3-dione-and W3-(2,5-dioxo-imidazolidin-4-yl)-urea (Allantoin)were extracted using column chromatography in this study. The existence of electronegative elements "oxygen, carbon, and hydrogen," which is a defining property of an 
TABLE 3: Phytocompounds identified through GC-MS analysis of EA1.

\begin{tabular}{|c|c|c|c|c|c|c|}
\hline Peak & Retention time & Area $(\%)$ & Height (\%) & Phytocompounds & Compounds (\%) & Base $(m / z)$ \\
\hline 1 & 12.934 & 0.37 & 0.49 & Dodecane & 0.37 & 57.05 \\
\hline 2 & 15.291 & 0.62 & 0.91 & Pentadecane & 0.62 & 57.05 \\
\hline 3 & 17.542 & 3.30 & 4.75 & Heptadecane & 3.30 & 57.05 \\
\hline 4 & 18.074 & 0.34 & 0.52 & Caryophyllene & 0.34 & 93.10 \\
\hline 5 & 19.165 & 1.59 & 2.04 & $\alpha$-Guaiene & 1.59 & 105.10 \\
\hline 6 & 19.402 & 0.53 & 0.84 & Nonadecane & 0.53 & 57.05 \\
\hline 7 & 19.449 & 0.63 & 1.09 & 4,5-di-epi-Aristolochene & 0.63 & 105.05 \\
\hline 8 & 19.654 & 1.34 & 1.95 & Hexadecane & 1.34 & 57.05 \\
\hline 9 & 19.707 & 0.97 & 1.48 & $5, \beta, 10, \alpha$-Eudesma-4(14),11-diene & 0.97 & 105.05 \\
\hline 10 & 19.821 & 3.06 & 2.80 & Phenol, 2,4-bis(1,1-dimethylethyl) & 3.06 & 191.15 \\
\hline 11 & 20.072 & 0.89 & 1.02 & Cubedol & 0.89 & 161.15 \\
\hline 12 & 20.709 & 1.30 & 1.75 & Elemol & 1.30 & 59.05 \\
\hline 13 & 21.447 & 0.55 & 0.79 & Caryophyllene oxide & 0.55 & 79.05 \\
\hline 14 & 21.507 & 0.48 & 0.75 & Centene & 0.48 & 55.05 \\
\hline 15 & 21.918 & 4.29 & 5.52 & Ledol & 4.29 & 69.05 \\
\hline 16 & 22.398 & 1.87 & 2.46 & Ledene oxide-(I) & 1.87 & 125.10 \\
\hline 17 & 22.525 & 0.41 & 0.52 & trans-Z- $\alpha$-Bisabolene epoxide & 0.41 & 136.10 \\
\hline 18 & 22.688 & 2.50 & 2.13 & $\delta$-Cadinol & 2.50 & 161.15 \\
\hline 19 & 22.742 & 1.02 & 1.18 & 3-Methyldiadamantane & 1.02 & 187.15 \\
\hline 20 & 22.883 & 1.34 & 1.10 & $\beta$-Eudesmol & 1.34 & 59.05 \\
\hline 21 & 22.958 & 0.56 & 0.67 & $\begin{array}{l}\text { 2-Butyloxycarbonyloxy-1,1,10-trimethyl-6,9- } \\
\text { epidioxydecalin }\end{array}$ & 0.56 & 57.05 \\
\hline 22 & 23.033 & 0.98 & 0.60 & Octadecane, 1-chloro- & 0.98 & 57.05 \\
\hline 23 & 23.192 & 0.79 & 0.46 & Limonen-6-ol, pivalate & 0.79 & 57.05 \\
\hline 24 & 23.498 & 27.74 & 12.50 & 1,5,5-Trimethyl-6-(3-methyl-buta-1,3-dienyl)-cyclohexene & 27.74 & 147.10 \\
\hline 25 & 23.636 & 0.29 & 0.42 & Heptadecane, 2,6,10,15-tetramethyl- & 0.29 & 57.05 \\
\hline 26 & 23.758 & 2.39 & 3.12 & Globulol & 2.39 & 81.05 \\
\hline 27 & 24.295 & 0.26 & 0.41 & $\begin{array}{l}\text { 7-Acetyl-2-hydroxy-2-methyl-isopropylbicyclo[4.3.0] } \\
\text { nonane }\end{array}$ & 0.26 & 153.10 \\
\hline 28 & 25.265 & 4.12 & 5.78 & E-15-Heptadecenal & 4.12 & 57.05 \\
\hline 29 & 25.375 & 0.57 & 0.92 & Octadecane & 0.57 & 57.05 \\
\hline 30 & 25.450 & 0.86 & 0.74 & 3-Hexadecanol & 0.86 & 57.05 \\
\hline 31 & 25.760 & 0.25 & 0.40 & Ethyl iso-allocholate & 0.25 & 60.00 \\
\hline 32 & 25.822 & 0.22 & 0.36 & Isoaromadendrene epoxide & 0.22 & 93.10 \\
\hline 33 & 26.002 & 0.97 & 1.69 & Neophytadiene & 0.97 & 57.05 \\
\hline 34 & 26.106 & 0.67 & 0.67 & Dihydrophytol & 0.67 & 57.05 \\
\hline 35 & 26.675 & 0.38 & 0.46 & Tricosane & 0.38 & 57.05 \\
\hline 36 & 26.740 & 0.73 & 0.99 & 2-Methyltetracosane & 0.73 & 57.05 \\
\hline 37 & 27.142 & 0.66 & 0.87 & Cholest-22-ene-21-ol,3,5-dehydro-6-methoxy-, pivalate & 0.66 & 57.05 \\
\hline 38 & 27.274 & 0.90 & 1.46 & Eicosane & 0.90 & 57.05 \\
\hline 39 & 27.490 & 0.68 & 0.85 & Hexadecanoic acid, methyl ester & 0.68 & 74.05 \\
\hline 40 & 27.729 & 2.22 & 2.21 & 1,1-Dimethyldecahydronaphthalene & 2.22 & 151.10 \\
\hline 41 & 27.977 & 0.41 & 0.73 & 2-Bromotetradecane & 0.41 & 149.00 \\
\hline 42 & 28.647 & 2.05 & 2.40 & 1-Octadecene & 2.05 & 57.05 \\
\hline 43 & 29.073 & 0.37 & 0.51 & Tridecanal & 0.37 & 57.05 \\
\hline 44 & 30.077 & 0.50 & 0.69 & 1-Decanol, 2-octyl- & 0.50 & 57.05 \\
\hline 45 & 30.178 & 0.83 & 1.03 & Methyl 10-trans,12-cis-octadecadienoate & 0.83 & 67.05 \\
\hline 46 & 30.293 & 1.56 & 1.21 & 9-Octadecenoic acid (z)-, methyl ester & 1.56 & 55.05 \\
\hline 47 & 30.457 & 0.72 & 0.87 & Phytol & 0.72 & 71.05 \\
\hline 48 & 30.636 & 0.87 & 1.26 & Docosane & 0.87 & 57.05 \\
\hline 49 & 31.044 & 0.80 & 0.84 & Ethyl 9,12-hexadecadienoate & 0.80 & 81.05 \\
\hline 50 & 31.285 & 0.92 & 0.91 & 2-Methylhexacosane & 0.92 & 57.05 \\
\hline 51 & 31.760 & 4.91 & 6.44 & 1-Heneicosanol & 4.91 & 57.05 \\
\hline
\end{tabular}

essential oil, was verified by FT-IR analysis of EA1. The volatile oil is also known as an essential oil, and the GCMS data showed the existence of a volatile antioxidant molecule termed heptadecane, which reduces pro-inflammatory gene expression [17]. Similarly, "ledol," a sesquiterpene, has anti-inflammatory and NF- $\kappa \mathrm{B}$ inhibitory characteristics [18], and phenol, 2,4-bis $(1,1$, dimethylethyl), is an anti-inflammatory, analgesic, and antioxidant molecule [19]. EA1 also included anti-inflammatory compounds such as globulol [20] and hexadecanoic acid [21]. Analgesic and antipyretic properties of neophytadiene have been observed [22]. 


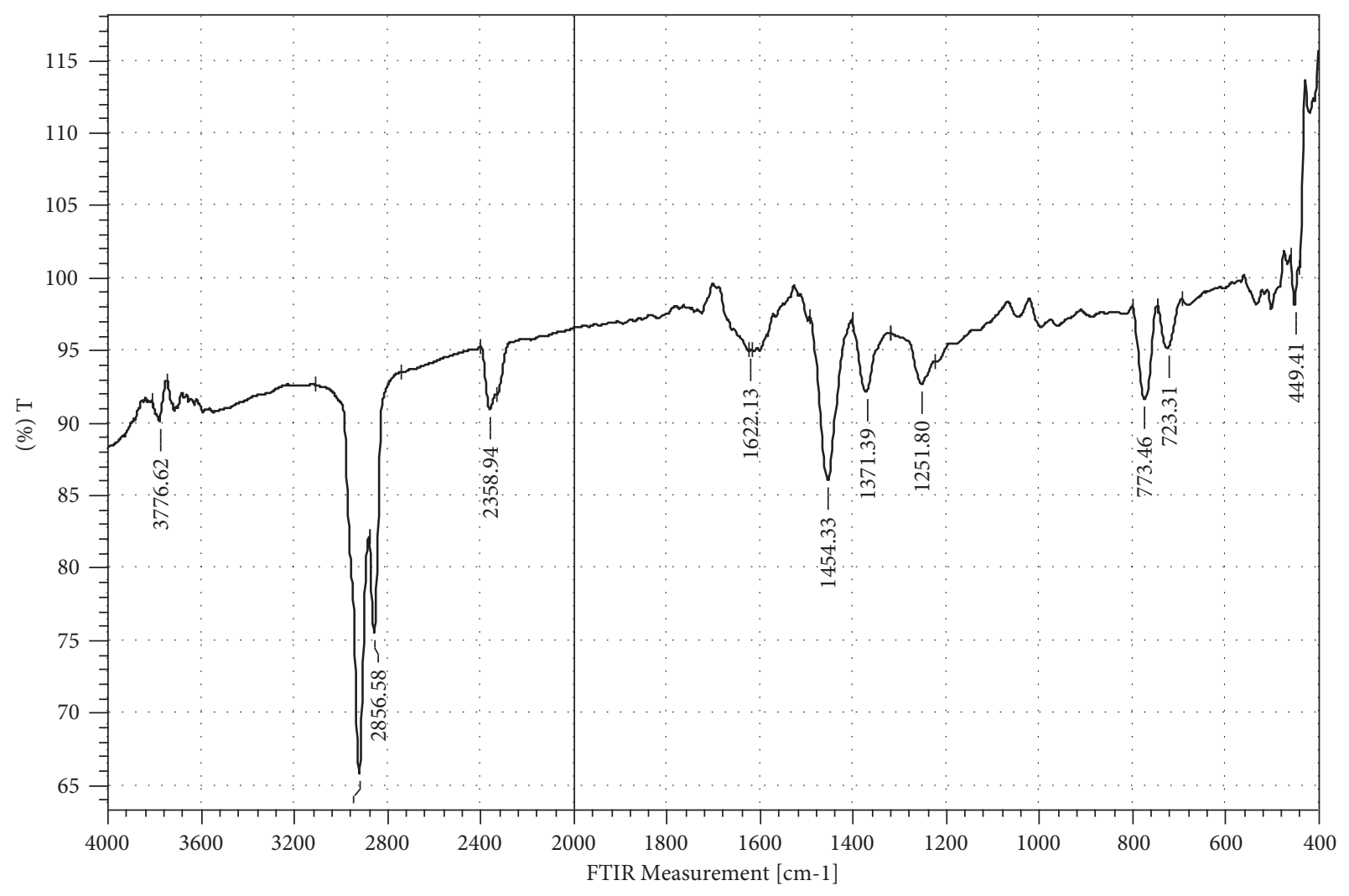

_ Smoothing

(a)
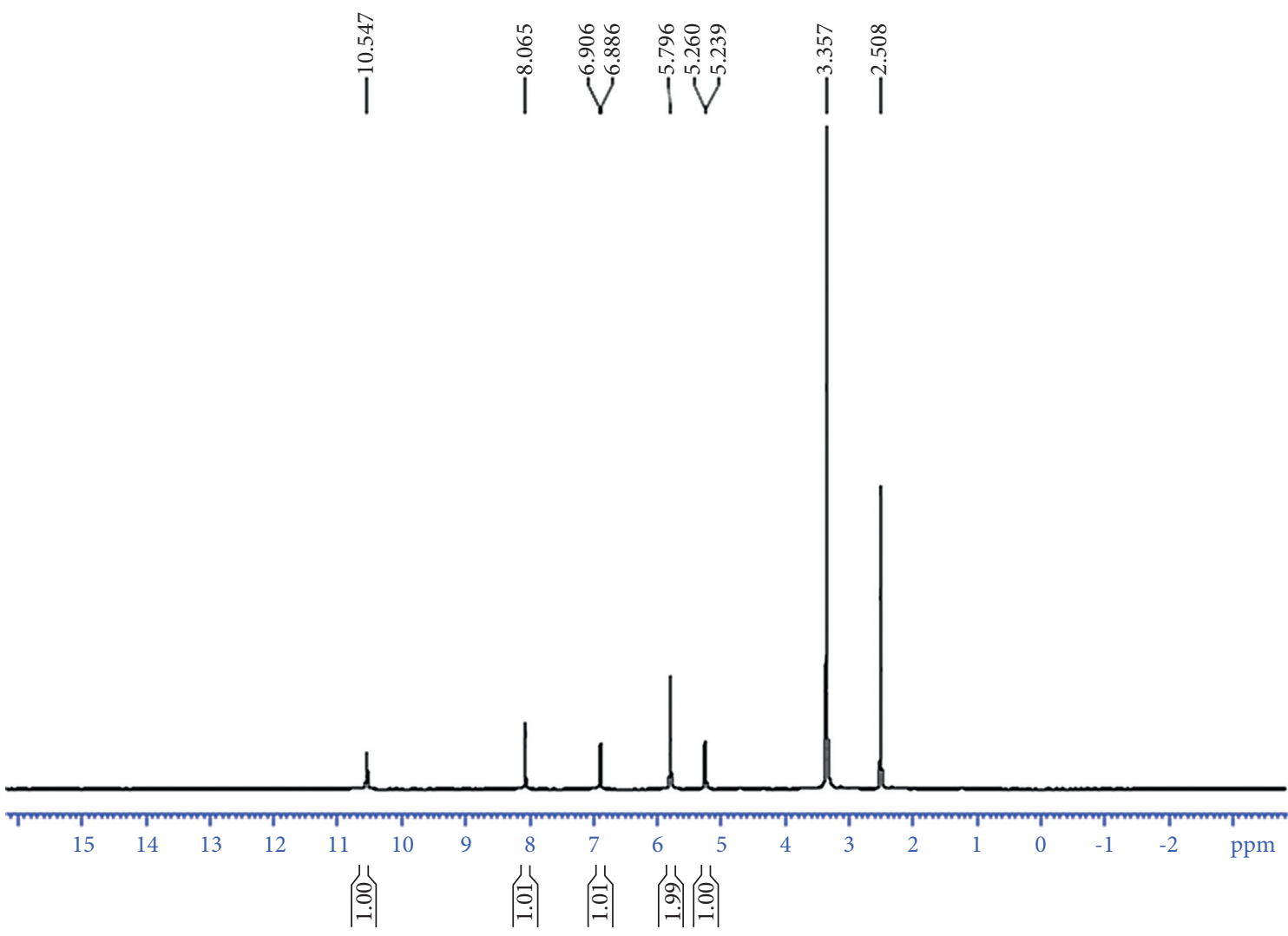

(b)

FIGURE 2: Continued. 


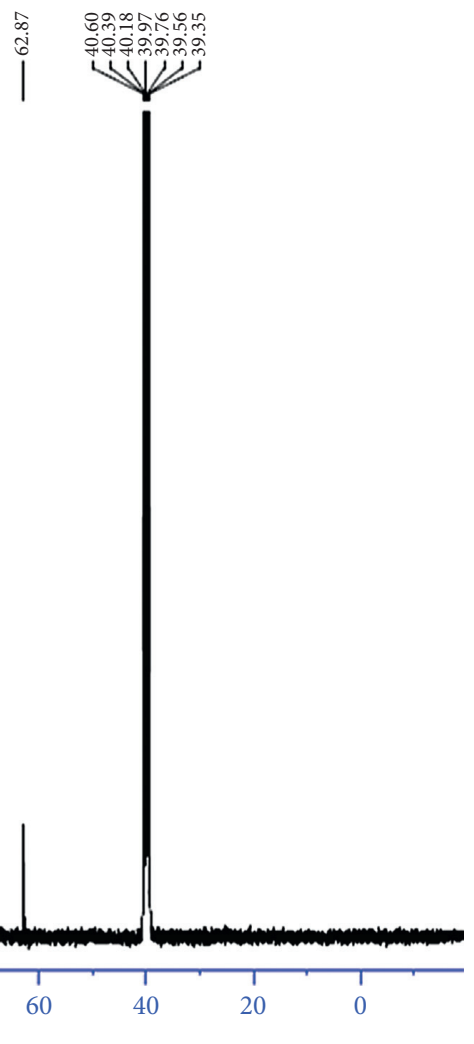

(c)

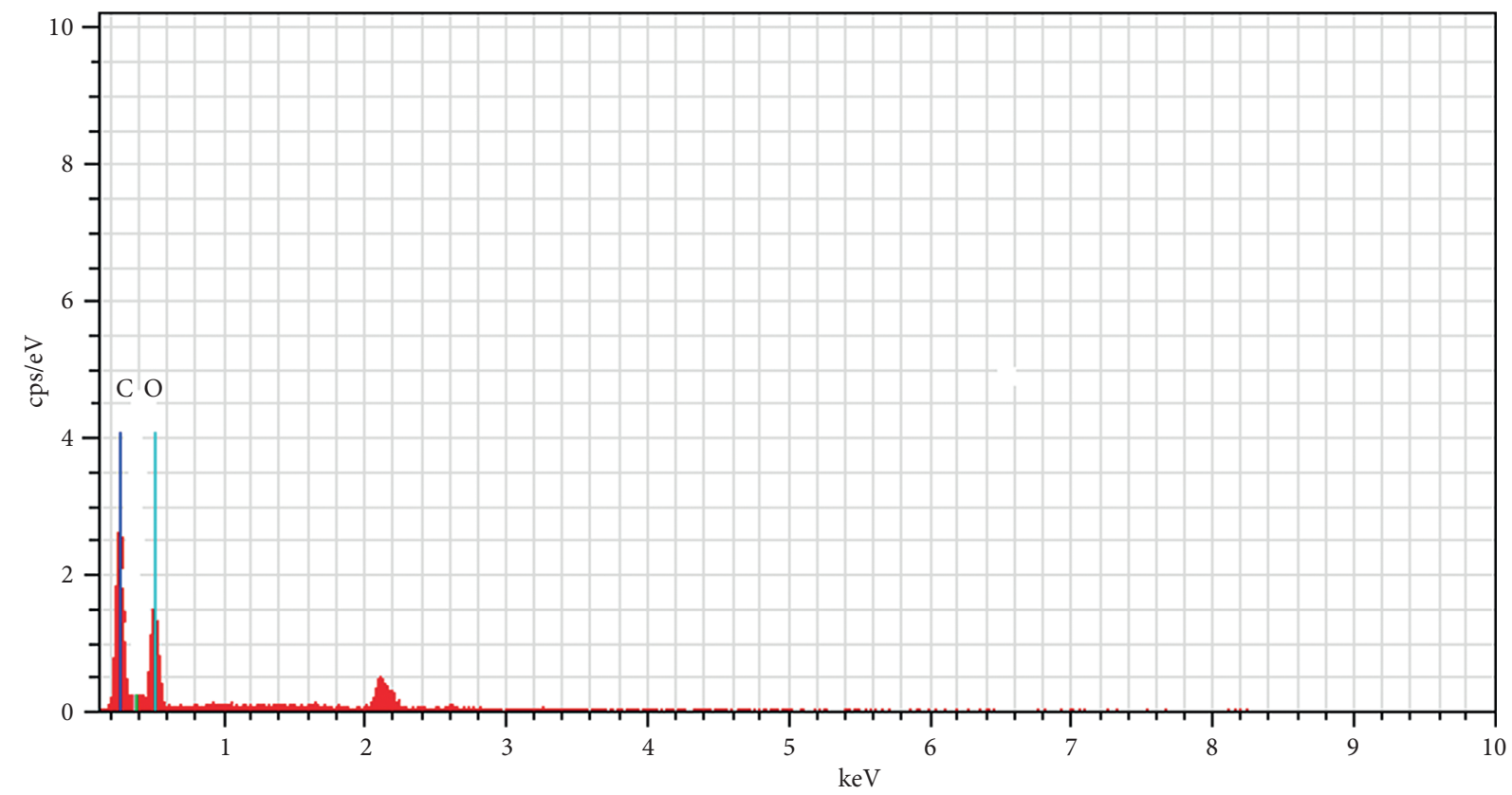

(d)<smiles>CC(=O)CC1C=CCC1=O</smiles>

(e)

FIGURE 2: (a) FT-IR spectrum of compound AA2. (b) ${ }^{1} \mathrm{H}-\mathrm{NMR}$ spectrum of compound AA2. (c) ${ }^{13} \mathrm{C}-\mathrm{NMR}$ spectrum of compound AA2. (d) EDX spectrum of compound AA2. (e) Chemical structure of compound AA2. 
TABLE 4: Bond length of compound AA2.

\begin{tabular}{lc}
\hline Elements & Bond length \\
\hline O1-C2 & $1.250(4)$ \\
O3-C6 & $1.222(5)$ \\
C1-C2 & $1.338(5)$ \\
C1-H1B & 0.93 \\
C5-C6 & $1.336(5)$ \\
C5-H5 & 0.93 \\
C7-C6 & $1.395(5)$ \\
C3-C2 & $1.353(5)$ \\
O2-C8 & $1.208(4)$ \\
C7-C8 & $1.361(5)$ \\
C1-H1A & 0.93 \\
C8-C4 & $1.536(5)$ \\
C3-H3 & 0.93 \\
C5-C4 & $1.462(5)$ \\
C7-H7 & 0.93 \\
C3-C4 & $1.422(4)$ \\
C4-H4 & 0.98 \\
\hline
\end{tabular}

TABLE 5: Bond angle of compound AA2.

\begin{tabular}{lc}
\hline Elements & Bond angle \\
\hline C8-C7-C6 & $111.6(3)$ \\
C6-C7-H7 & 124.2 \\
C2-C3-H3 & 119.6 \\
C6-C5-C4 & $112.3(3)$ \\
C4-C5-H5 & 123.8 \\
C2-C1-H1B & 120.0 \\
C2-C1-H1A & 120.0 \\
H1A-C1-H1B & 120.0 \\
C3-C4-C5 & $115.9(3)$ \\
O1-C2-C1 & $122.6(3)$ \\
C1-C2-C3 & $117.3(3)$ \\
O2-C8-C4 & $126.7(3)$ \\
O3-C6-C5 & $127.8(4)$ \\
C5-C6-C7 & $108.1(3)$ \\
C3-C4-C8 & $113.7(3)$ \\
O1-C2-C3 & $120.0(3)$ \\
O2-C8-C7 & $126.6(3)$ \\
C5-C4-C8 & $100.9(3)$ \\
C3-C4-H4 & 108.6 \\
C8-C4-H4 & 108.6 \\
C8-C7-H7 & 124.2 \\
C2-C3-C4 & $120.8(3)$ \\
C4-C3-H3 & 119.6 \\
C6-C5-H5 & 123.8 \\
C7-C8-C4 & $106.6(3)$ \\
O3-C6-C7 & $124.1(3)$ \\
C5-C4-H4 & 108.6 \\
\hline
\end{tabular}

The crystal AA2 is a new compound that resembles the structure of 2-methyl-1,3-cyclopentanedione, which was patented (US2016168190) for its composition and to treat traumatic brain injury (TBI); dermatological disorders such as wounds, scars, itching, and ulcers (A61P17/02); joint diseases such as arthritis and arthrosis (A61P19/08); and bone diseases such as rachitis. The crystal W3 is an Allantoin, which is a well-known chemical (PubChem CID: 204) possessing anti-inflammatory, anti-healing, and anti-irritating characteristics. Because of its capacity to heal tiny wounds and promote healthy skin, Allantoin is a common
TABle 6: Atomic coordinates and equivalent isotropic atomic displacement parameters $\left(\AA^{2}\right)$ of compound AA2.

\begin{tabular}{|c|c|c|c|c|}
\hline & $x / a$ & $y / b$ & $z / c$ & $U$ (eq) \\
\hline $\mathrm{O} 1$ & $0.7643(3)$ & $0.8942(5)$ & $0.75373(18)$ & $0.0358(8)$ \\
\hline $\mathrm{O} 2$ & $0.9293(3)$ & $0.6791(6)$ & $0.57912(18)$ & $0.0370(8)$ \\
\hline $\mathrm{O} 3$ & $0.3646(3)$ & $0.7877(6)$ & $0.5629(2)$ & $0.0429(8)$ \\
\hline $\mathrm{C} 7$ & $0.6512(4)$ & $0.7739(6)$ & $0.5521(2)$ & $0.0234(8)$ \\
\hline C3 & $0.7878(4)$ & $0.4585(6)$ & $0.7473(2)$ & $0.0226(7)$ \\
\hline C5 & $0.5341(4)$ & $0.5166(7)$ & $0.6502(2)$ & $0.0271(8)$ \\
\hline $\mathrm{C} 1$ & $0.8927(4)$ & $0.6810(7)$ & $0.8725(2)$ & $0.0280(8)$ \\
\hline $\mathrm{C} 2$ & $0.8141(4)$ & $0.6876(7)$ & $0.7904(2)$ & $0.0286(8)$ \\
\hline $\mathrm{C} 8$ & $0.7836(4)$ & $0.6476(7)$ & $0.5933(2)$ & $0.0289(8)$ \\
\hline C6 & $0.5008(5)$ & $0.6990(7)$ & $0.5876(2)$ & $0.0318(9)$ \\
\hline $\mathrm{C} 4$ & $0.7115(4)$ & $0.4498(7)$ & $0.6583(2)$ & $0.0302(8)$ \\
\hline
\end{tabular}

$U$ (eq) is defined as one-third of the trace of the orthogonalized $U i j$ tensor.

TABLE 7: Torsion angles $\left({ }^{\circ}\right)$ of compound AA2.

\begin{tabular}{lc}
\hline Elements & Torsion angles $\left(^{\circ}\right)$ \\
\hline C4-C3-C2-O1 & $3.3(5)$ \\
C6-C7-C8-O2 & $-177.2(3)$ \\
C4-C5-C6-O3 & $176.9(4)$ \\
C8-C7-C6-O3 & $178.9(4)$ \\
C2-C3-C4-C5 & $-70.0(5)$ \\
C6-C5-C4-C3 & $128.1(3)$ \\
O2-C8-C4-C3 & $51.7(5)$ \\
O2-C8-C4-C5 & $176.5(4)$ \\
C4-C3-C2-C1 & $-177.4(3)$ \\
C6-C7-C8-C4 & $5.0(4)$ \\
C4-C5-C6-C7 & $-2.1(4)$ \\
C8-C7-C6-C5 & $-2.0(4)$ \\
C2-C3-C4-C8 & $46.3(5)$ \\
C6-C5-C4-C8 & $4.8(4)$ \\
C7-C8-C4-C3 & $-130.6(3)$ \\
C7-C8-C4-C5 & $-5.8(4)$ \\
\hline
\end{tabular}

TABle 8: Anisotropic atomic displacement parameters $\left(\AA^{2}\right)$ of compound AA2.

\begin{tabular}{cccccc}
\hline & $U_{11}$ & $U_{22}$ & $U_{33}$ & $U_{23}$ & $U_{13}$ \\
\hline O1 & $0.0426(15)$ & $0.0273(14)$ & $0.0365(14)$ & $0.0000(11)$ & $\begin{array}{c}-0.0060 \\
(11)\end{array}$ \\
O2 & $0.0293(14)$ & $0.0446(17)$ & $0.0366(15)$ & $0.0052(11)$ & $\begin{array}{c}0.0018 \\
(11)\end{array}$ \\
O3 & $0.0308(15)$ & $0.0506(18)$ & $0.0465(16)$ & $0.0092(13)$ & $\begin{array}{c}-0.0055 \\
(12)\end{array}$ \\
C7 & $0.0228(15)$ & $0.0276(16)$ & $0.0194(14)$ & $0.0065(12)$ & $\begin{array}{c}-0.0027 \\
(11)\end{array}$ \\
C3 & $0.0301(16)$ & $0.0188(15)$ & $0.0181(14)$ & $0.0023(11)$ & $\begin{array}{c}-0.0069 \\
(11)\end{array}$ \\
C5 & $0.0199(15)$ & $0.0334(18)$ & $0.0276(16)$ & $0.0089(13)$ & $\begin{array}{c}-0.0040 \\
(12)\end{array}$ \\
C1 & $0.0336(17)$ & $0.0281(17)$ & $0.0213(15)$ & $0.0010(12)$ & $\begin{array}{c}-0.0085 \\
(12)\end{array}$ \\
C2 & $0.0280(16)$ & $0.0297(18)$ & $0.0278(17)$ & $0.0006(13)$ & $\begin{array}{c}0.0010 \\
(13)\end{array}$ \\
C8 & $0.0297(17)$ & $0.0309(17)$ & $0.0256(16)$ & $-0.0019(13)$ & $\begin{array}{c}-0.0034 \\
(13)\end{array}$ \\
C6 & $0.0300(18)$ & $0.0348(19)$ & $0.0299(17)$ & $-0.0011(14)$ & $\begin{array}{c}-0.0050 \\
(13)\end{array}$ \\
\hline
\end{tabular}

The anisotropic atomic displacement factor exponent takes the form $-2 \pi 2[h 2 a * 2 U 11+\cdots+2 h k a * b * U 12]$. 
TABLE 9: Hydrogen atomic coordinates and isotropic atomic displacement parameters $\left(\AA^{2}\right)$ of compound AA2.

\begin{tabular}{lcccc}
\hline & $x / a$ & $y / b$ & $z / c$ & $U(\mathrm{eq})$ \\
\hline H7 & 0.6598 & 0.8952 & 0.5060 & 0.028 \\
H3 & 0.8200 & 0.3047 & 0.7762 & 0.027 \\
H5 & 0.4536 & 0.4407 & 0.6847 & 0.033 \\
H1A & 0.9122 & 0.8342 & 0.9046 & 0.034 \\
H1B & 0.9278 & 0.5233 & 0.8974 & 0.034 \\
H4 & 0.7260 & 0.2752 & 0.6337 & 0.036 \\
\hline
\end{tabular}

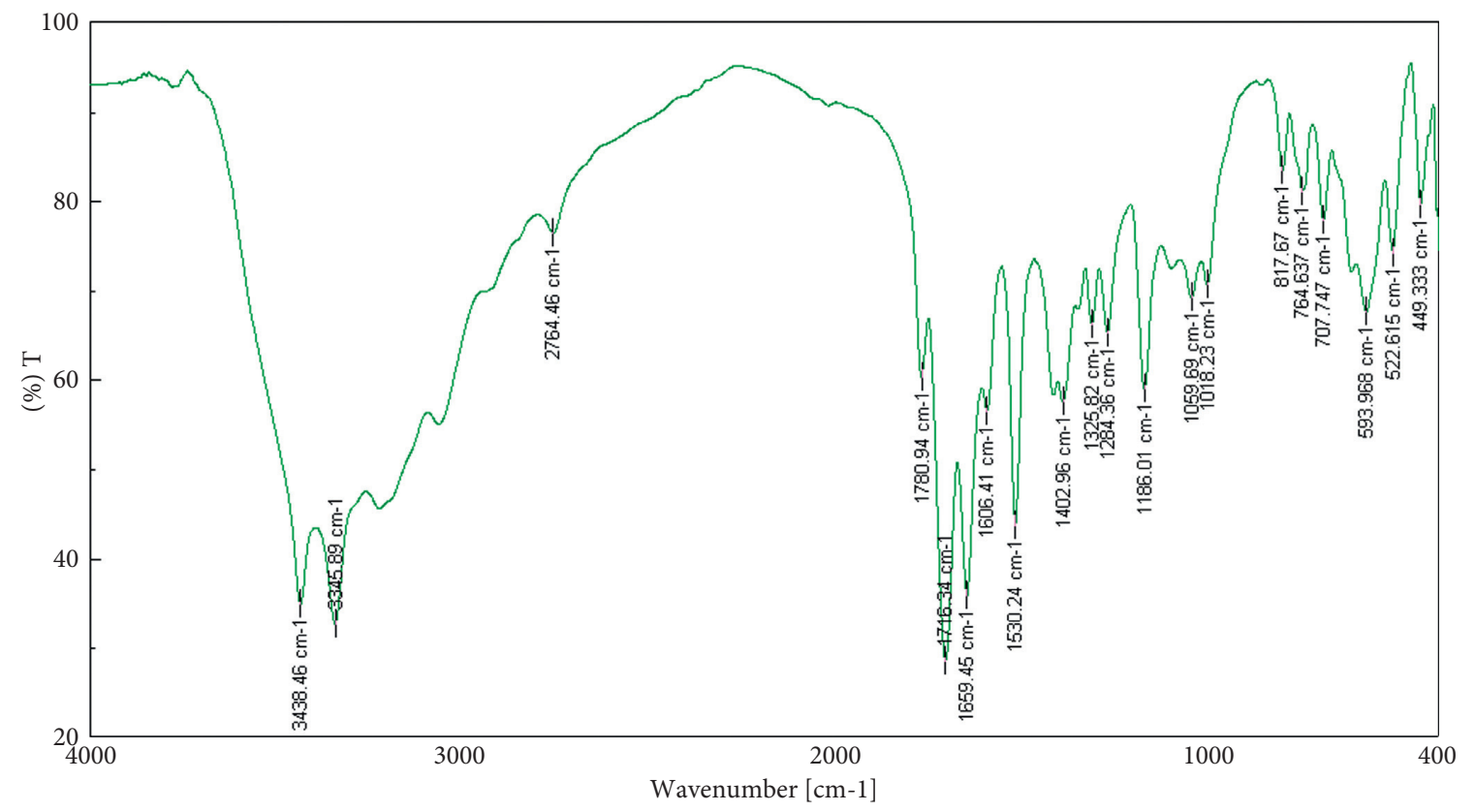

(a)
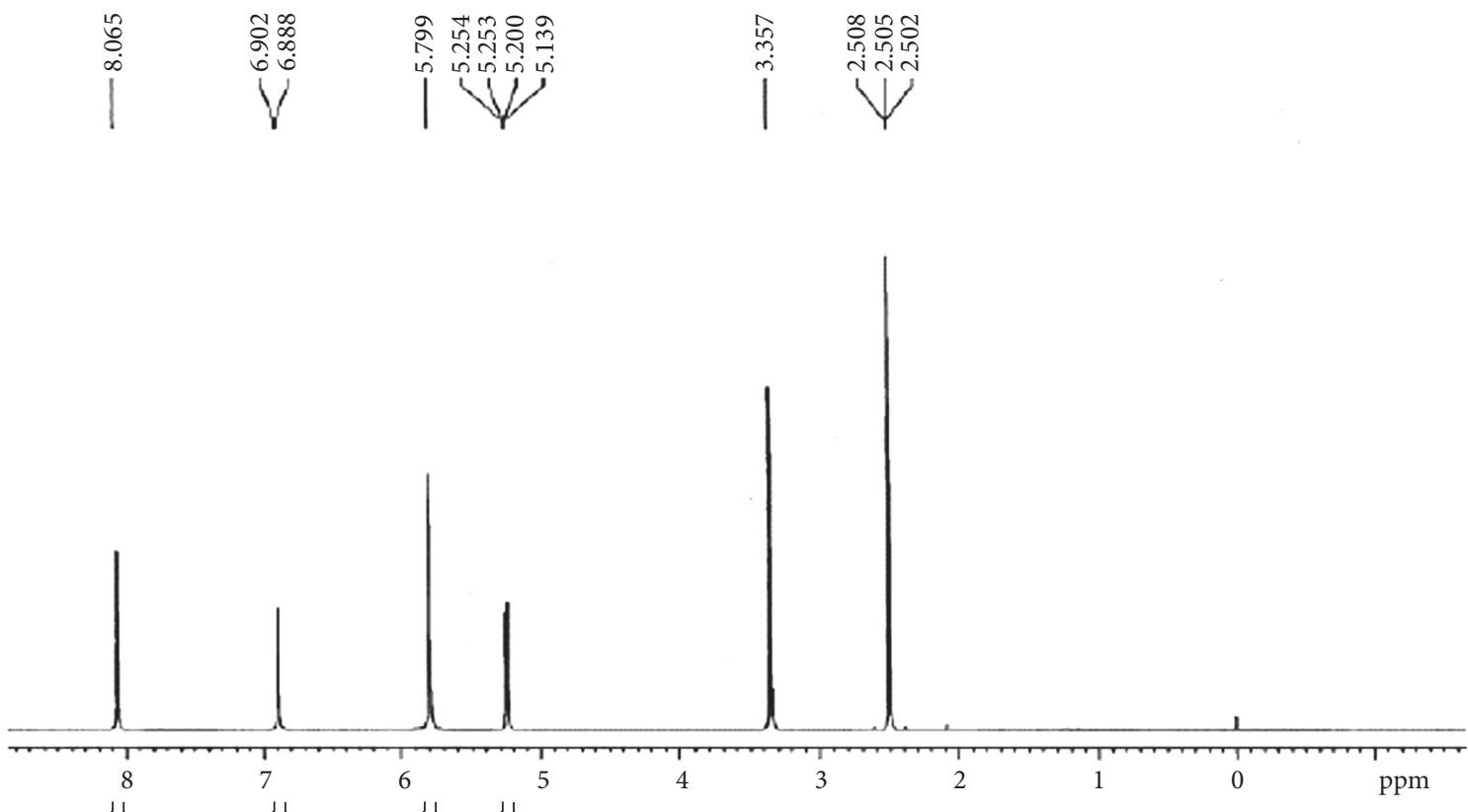

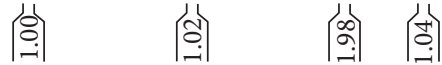

(b)

Figure 3: Continued. 


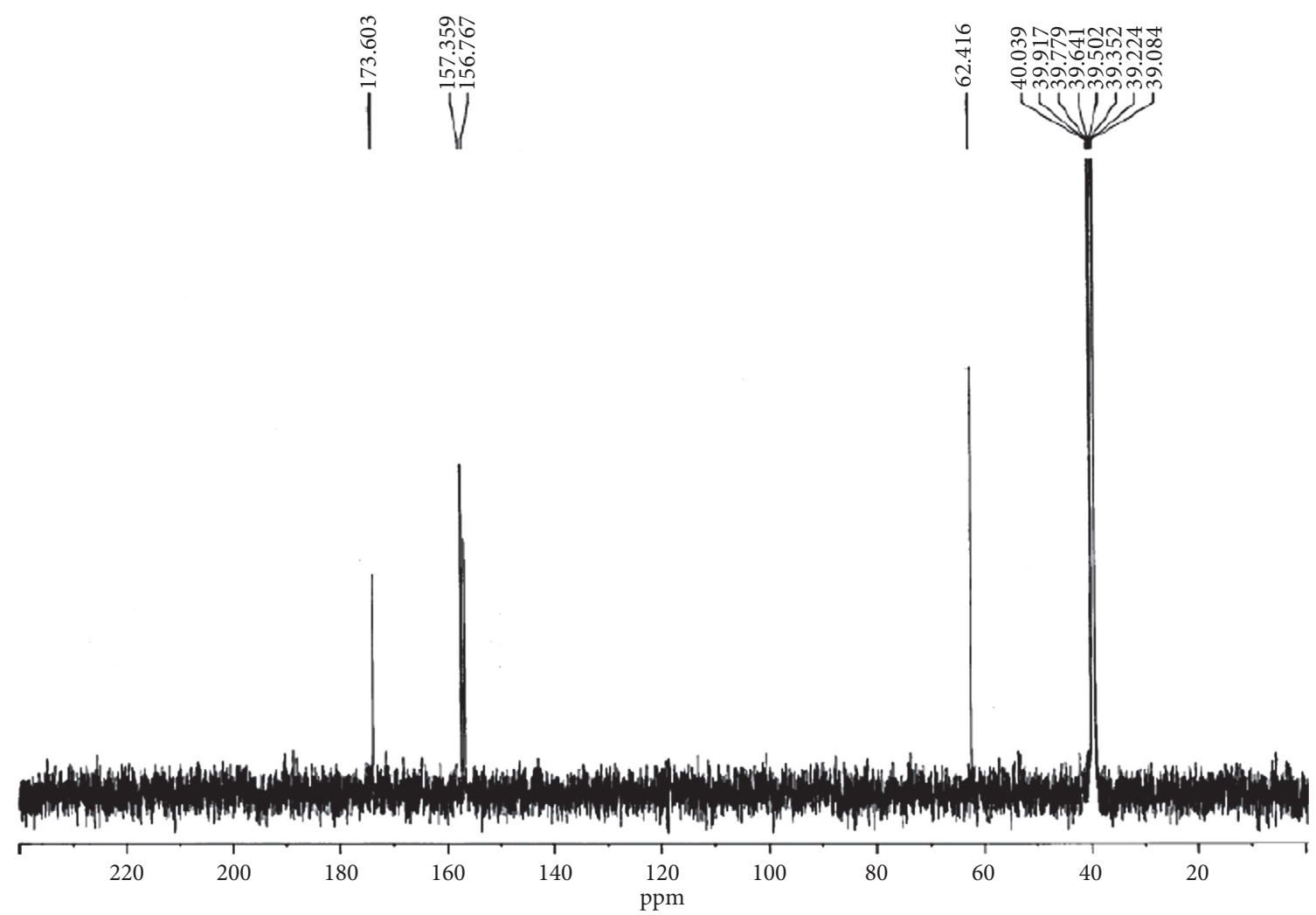

(c)

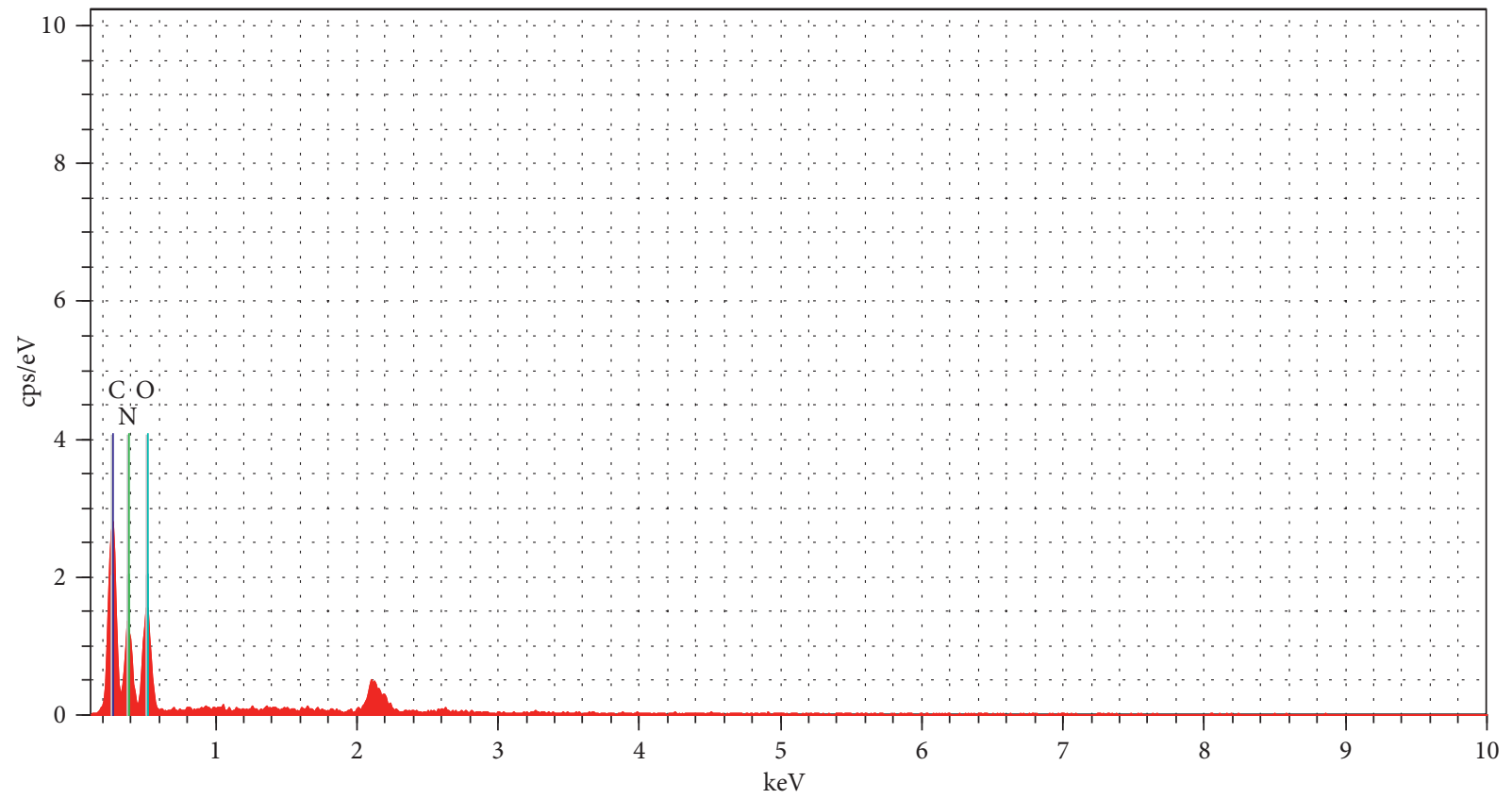

(d)

FIgUre 3: Continued. 


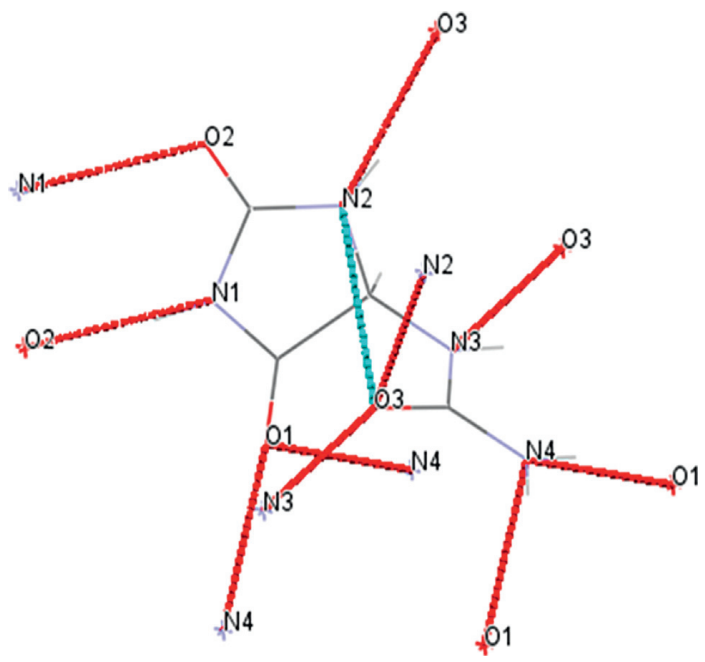

(e)

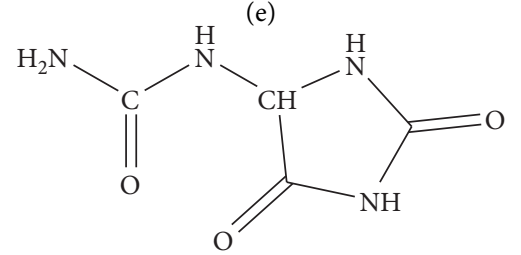

(f)

FIgURE 3: (a) FT-IR spectrum of compound W3. (b) ${ }^{1} \mathrm{H}-\mathrm{NMR}$ spectrum of compound W3. (c) ${ }^{13} \mathrm{C}-\mathrm{NMR}$ spectrum of compound W3. (d) EDX spectrum of compound W3. (e) Hydrogen bonding of compound W3. (f) Chemical structure of compound W3.

TABLE 10: Bond length of compound W3.

\begin{tabular}{lc}
\hline Elements & Bond length \\
\hline $\mathrm{O}(1)-\mathrm{C}(1)$ & $1.218(2)$ \\
$\mathrm{O}(2)-\mathrm{C}(2)$ & $1.225(2)$ \\
$\mathrm{O}(3)-\mathrm{C}(4)$ & $1.245(2)$ \\
$\mathrm{N}(1)-\mathrm{C}(1)$ & $1.352(2)$ \\
$\mathrm{N}(1)-\mathrm{C}(2)$ & $1.393(2)$ \\
$\mathrm{N}(1)-\mathrm{H}(1 \mathrm{~N})$ & $0.87(2)$ \\
$\mathrm{N}(2)-\mathrm{C}(2)$ & $1.336(2)$ \\
$\mathrm{N}(2)-\mathrm{C}(3)$ & $1.460(2)$ \\
$\mathrm{N}(2)-\mathrm{H}(2 \mathrm{~N})$ & $0.82(2)$ \\
$\mathrm{N}(3)-\mathrm{C}(4)$ & $1.357(2)$ \\
$\mathrm{N}(3)-\mathrm{C}(3)$ & $1.425(2)$ \\
$\mathrm{N}(3)-\mathrm{H}(3 \mathrm{~B})$ & 0.8600 \\
$\mathrm{~N}(4)-\mathrm{C}(4)$ & $1.333(2)$ \\
$\mathrm{N}(4)-\mathrm{H}(4 \mathrm{~A})$ & 0.8600 \\
$\mathrm{~N}(4)-\mathrm{H}(4 \mathrm{~B})$ & 0.8600 \\
$\mathrm{C}(1)-\mathrm{C}(3)$ & $1.537(2)$ \\
$\mathrm{C}(3)-\mathrm{H}(3 \mathrm{~A})$ & 0.9800 \\
\hline
\end{tabular}

ingredient in anti-acne treatments, sun care products, and clarifying lotions. It is also found in mouthwash, toothpaste, shampoos, lipsticks, other cosmetic lotions, creams, and medicinal items [23].

The capacity of a medication to scavenge free radicals is seen as crucial. Many studies have shown a significant link between antioxidant and antivenom action of substances [24]. EA1 had higher antioxidant activity because it included
TABLE 11: Bond angle of compound W3.

\begin{tabular}{lc}
\hline Elements & Bond angle \\
\hline $\mathrm{C}(1)-\mathrm{N}(1)-\mathrm{C}(2)$ & $112.04(15)$ \\
$\mathrm{C}(1)-\mathrm{N}(1)-\mathrm{H}(1 \mathrm{~N})$ & $123.8(14)$ \\
$\mathrm{C}(2)-\mathrm{N}(1)-\mathrm{H}(1 \mathrm{~N})$ & $123.8(14)$ \\
$\mathrm{C}(2)-\mathrm{N}(2)-\mathrm{C}(3)$ & $112.39(14)$ \\
$\mathrm{C}(2)-\mathrm{N}(2)-\mathrm{H}(2 \mathrm{~N})$ & $124.0(17)$ \\
$\mathrm{C}(3)-\mathrm{N}(2)-\mathrm{H}(2 \mathrm{~N})$ & $123.6(17)$ \\
$\mathrm{C}(4)-\mathrm{N}(3)-\mathrm{C}(3)$ & $120.46(14)$ \\
$(4)-\mathrm{N}(3)-\mathrm{H}(3 \mathrm{~B})$ & 119.8 \\
$\mathrm{C}(3)-\mathrm{N}(3)-\mathrm{H}(3 \mathrm{~B})$ & 119.8 \\
$\mathrm{C}(4)-\mathrm{N}(4)-\mathrm{H}(4 \mathrm{~A})$ & 120.0 \\
$\mathrm{C}(4)-\mathrm{N}(4)-\mathrm{H}(4 \mathrm{~B})$ & 120.0 \\
$\mathrm{H}(4 \mathrm{~A})-\mathrm{N}(4)-(4 \mathrm{~B})$ & 120.0 \\
$\mathrm{O}(1)-\mathrm{C}(1)-\mathrm{N}(1)$ & $127.20(16)$ \\
$\mathrm{O}(1)-\mathrm{C}(1)-\mathrm{C}(3)$ & $126.15(15)$ \\
$\mathrm{N}(1)-\mathrm{C}(1)-\mathrm{C}(3)$ & $106.60(14)$ \\
$\mathrm{O}(2)-\mathrm{C}(2)-\mathrm{N}(2)$ & $127.76(17)$ \\
$\mathrm{O}(2)-\mathrm{C}(2)-\mathrm{N}(1)$ & $124.40(16)$ \\
$\mathrm{N}(2)-\mathrm{C}(2)-\mathrm{N}(1)$ & $107.84(15)$ \\
$\mathrm{N}(3)-\mathrm{C}(3)-\mathrm{N}(2)$ & $116.20(14)$ \\
$\mathrm{N}(3)-\mathrm{C}(3)-\mathrm{C}(1)$ & $113.80(14)$ \\
$\mathrm{N}(2)-\mathrm{C}(3)-\mathrm{C}(1)$ & $100.80(13)$ \\
$\mathrm{N}(3)-\mathrm{C}(3)-\mathrm{H}(3 \mathrm{~A})$ & 108.5 \\
$\mathrm{~N}(2)-\mathrm{C}(3)-\mathrm{H}(3 \mathrm{~A})$ & 108.5 \\
$\mathrm{C}(1)-\mathrm{C}(3)-\mathrm{H}(3 \mathrm{~A})$ & 108.5 \\
$\mathrm{O}(3)-\mathrm{C}(4)-\mathrm{N}(4)$ & $122.81(16)$ \\
$\mathrm{O}(3)-\mathrm{C}(4)-\mathrm{N}(3)$ & $120.16(16)$ \\
$\mathrm{N}(4)-\mathrm{C}(4)-\mathrm{N}(3)$ & $117.02(15)$ \\
\hline &
\end{tabular}


TABLE 12: Distance between hydrogen acceptor and donor of compound W3.

\begin{tabular}{lcccc}
\hline$D-H \ldots A$ & $d(\mathrm{D}-\mathrm{H})$ & $d(\mathrm{H} \ldots \mathrm{A})$ & $d(\mathrm{D} \ldots \mathrm{A})$ & $<(\mathrm{DHA})$ \\
\hline $\mathrm{N}(1)-(1 \mathrm{~N}) \ldots \mathrm{O}(2) \#$ & $10.87(2)$ & $1.98(2)$ & $2.829(2)$ & $167(2)$ \\
$\mathrm{N}(2)-(2 \mathrm{~N}) \ldots \mathrm{O}(3) \#$ & $20.82(2)$ & $2.13(2)$ & $2.923(2)$ & $160(2)$ \\
$\mathrm{N}(3)-(3 \mathrm{~B}) \ldots \mathrm{O}(3) \#$ & 30.86 & 2.23 & $2.9115(19)$ & 136.2 \\
$\mathrm{~N}(4)-(4 \mathrm{~A}) \ldots \mathrm{O}(1) \#$ & 40.86 & 2.25 & $3.006(2)$ & 145.9 \\
$\mathrm{~N}(4)-(4 \mathrm{~B}) \ldots \mathrm{O}(1) \#$ & 60.86 & 2.20 & $3.023(2)$ & 161.2 \\
$\mathrm{C}(3)-(3 \mathrm{~A}) \ldots \mathrm{O}(3) \#$ & 30.98 & 2.66 & $3.212(2)$ & 116.0 \\
\hline
\end{tabular}

Symmetry transformations used to generate equivalent atoms: $\# 1-x+1,-y$, $-z+1 \# 2-x+1, y+1 / 2,-z+1 / 2 \# 3 x, y+1, z \# 4-x, y-1 / 2,-z+1 / 2 \# 5 x$, $-y+1 / 2, z-1 / 2 \# 6-x, y+1 / 2,-z+1 / 2$.

TABLE 13: Atomic coordinates $\left(\times 10^{4}\right)$ and equivalent isotropic displacement parameters $\left(\AA^{2} \times 10^{3}\right)$ of compound W3.

\begin{tabular}{lcccc}
\hline & $x$ & $Y$ & $z$ & $U(\mathrm{eq})$ \\
\hline $\mathrm{O}(1)$ & $703(2)$ & $3211(2)$ & $4209(1)$ & $31(1)$ \\
$\mathrm{O}(2)$ & $6355(2)$ & $2121(3)$ & $4371(1)$ & $37(1)$ \\
$\mathrm{O}(3)$ & $2354(2)$ & $1060(2)$ & $2461(1)$ & $30(1)$ \\
$\mathrm{N}(1)$ & $3488(2)$ & $2268(3)$ & $4477(1)$ & $27(1)$ \\
$\mathrm{N}(2)$ & $4656(2)$ & $4841(3)$ & $3501(1)$ & $31(1)$ \\
$\mathrm{N}(3)$ & $2121(2)$ & $5421(3)$ & $2526(1)$ & $26(1)$ \\
$\mathrm{N}(4)$ & $1081(2)$ & $3192(3)$ & $1277(1)$ & $32(1)$ \\
$\mathrm{C}(1)$ & $2170(2)$ & $3514(3)$ & $4069(1)$ & $24(1)$ \\
$\mathrm{C}(2)$ & $4990(2)$ & $3014(3)$ & $4126(1)$ & $27(1)$ \\
$\mathrm{C}(3)$ & $2886(2)$ & $5500(3)$ & $3418(1)$ & $25(1)$ \\
\hline
\end{tabular}

$U$ (eq) is defined as one-third of the trace of the orthogonalized $U^{i j}$ tensor.

TABle 14: Anisotropic displacement parameters $\left(\AA^{2} \times 10^{3}\right)$ of compound W3.

\begin{tabular}{lcccccc}
\hline & $U^{11}$ & $U^{22}$ & $U^{33}$ & $U^{23}$ & $U^{13}$ & $U^{12}$ \\
\hline $\mathrm{O}(1)$ & $26(1)$ & $32(1)$ & $35(1)$ & $6(1)$ & $4(1)$ & $2(1)$ \\
$\mathrm{O}(2)$ & $28(1)$ & $38(1)$ & $43(1)$ & $9(1)$ & $-1(1)$ & $5(1)$ \\
$\mathrm{O}(3)$ & $38(1)$ & $17(1)$ & $34(1)$ & $1(1)$ & $1(1)$ & $5(1)$ \\
$\mathrm{N}(1)$ & $30(1)$ & $25(1)$ & $26(1)$ & $5(1)$ & $2(1)$ & $3(1)$ \\
$\mathrm{N}(2)$ & $26(1)$ & $31(1)$ & $37(1)$ & $10(1)$ & $2(1)$ & $-4(1)$ \\
$\mathrm{N}(3)$ & $37(1)$ & $16(1)$ & $25(1)$ & $2(1)$ & $-2(1)$ & $3(1)$ \\
$\mathrm{N}(4)$ & $42(1)$ & $24(1)$ & $28(1)$ & $0(1)$ & $-5(1)$ & $-3(1)$ \\
$\mathrm{C}(1)$ & $31(1)$ & $20(1)$ & $22(1)$ & $-2(1)$ & $0(1)$ & $1(1)$ \\
$\mathrm{C}(2)$ & $30(1)$ & $23(1)$ & $28(1)$ & $-2(1)$ & $1(1)$ & $0(1)$ \\
$\mathrm{C}(3)$ & $28(1)$ & $17(1)$ & $29(1)$ & $-1(1)$ & $0(1)$ & $-1(1)$ \\
\hline
\end{tabular}

The anisotropic displacement factor exponent takes the form: $-2 \pi 2[h 2 a * 2 U 11+\cdots+2 h k a * b * U 12]$.

TABLE 15: Hydrogen coordinates $\left(\times 10^{4}\right)$ and isotropic displacement parameters $\left(\AA^{2} \times 10^{3}\right)$ of compound W3.

\begin{tabular}{lcccc}
\hline & $x$ & $y$ & $Z$ & $U(\mathrm{eq})$ \\
\hline $\mathrm{H}(1 \mathrm{~N})$ & $3400(30)$ & $1020(50)$ & $4866(15)$ & $31(5)$ \\
$\mathrm{H}(2 \mathrm{~N})$ & $5360(30)$ & $5500(50)$ & $3189(16)$ & $43(6)$ \\
$\mathrm{H}(3 \mathrm{~B})$ & 1825 & 6844 & 2259 & 31 \\
$\mathrm{H}(4 \mathrm{~A})$ & 908 & 1779 & 977 & 38 \\
$\mathrm{H}(4 \mathrm{~B})$ & 754 & 4653 & 1049 & 38 \\
$\mathrm{H}(3 \mathrm{~A})$ & 2739 & 7244 & 3666 & 30 \\
\hline
\end{tabular}

several antioxidant compounds such as eicosane $\left(\mathrm{C}_{20} \mathrm{H}_{42}\right)$, neophytadiene $\left(\mathrm{C}_{20} \mathrm{H}_{38}\right)$, 2-methyltetracosane $\left(\mathrm{C}_{25} \mathrm{H}_{52}\right)$, heptadecane $\left(\mathrm{C}_{17} \mathrm{H}_{36}\right)$, nonadecane $\left(\mathrm{C}_{19} \mathrm{H}_{40}\right)$, tetratricontane $\left(\mathrm{C}_{44} \mathrm{H}_{90}\right)$, sisterol $\left(\mathrm{C}_{29} \mathrm{H}_{50} \mathrm{O}\right)$, and 1-
TABLE 16: Torsion angles $\left({ }^{\circ}\right)$ of compound W3.

\begin{tabular}{lc}
\hline Elements & Torsion angles $\left(^{\circ}\right)$ \\
\hline $\mathrm{C}(2)-\mathrm{N}(1)-\mathrm{C}(1)-\mathrm{O}(1)$ & $177.48(16)$ \\
$\mathrm{C}(2)-\mathrm{N}(1)-\mathrm{C}(1)-\mathrm{C}(3)$ & $-5.09(19)$ \\
$\mathrm{C}(3)-\mathrm{N}(2)-\mathrm{C}(2)-\mathrm{O}(2)$ & $-177.39(17)$ \\
$\mathrm{C}(3)-\mathrm{N}(2)-\mathrm{C}(2)-\mathrm{N}(1)$ & $2.0(2)$ \\
$\mathrm{C}(1)-\mathrm{N}(1)-\mathrm{C}(2)-\mathrm{O}(2)$ & $-178.42(17)$ \\
$\mathrm{C}(1)-\mathrm{N}(1)-\mathrm{C}(2)-\mathrm{N}(2)$ & $2.2(2)$ \\
$\mathrm{C}(4)-\mathrm{N}(3)-\mathrm{C}(3)-\mathrm{N}(2)$ & $70.4(2)$ \\
$\mathrm{C}(4)-\mathrm{N}(3)-\mathrm{C}(3)-\mathrm{C}(1)$ & $-46.0(2)$ \\
$\mathrm{C}(2)-\mathrm{N}(2)-\mathrm{C}(3)-\mathrm{N}(3)$ & $-128.17(16)$ \\
$\mathrm{C}(2)-\mathrm{N}(2)-\mathrm{C}(3)-\mathrm{C}(1)$ & $-4.68(18)$ \\
$\mathrm{O}(1)-\mathrm{C}(1)-\mathrm{C}(3)-\mathrm{N}(3)$ & $-51.7(2)$ \\
$\mathrm{N}(1)-\mathrm{C}(1)-\mathrm{C}(3)-\mathrm{N}(3)$ & $130.82(15)$ \\
$\mathrm{O}(1)-\mathrm{C}(1)-\mathrm{C}(3)-\mathrm{N}(2)$ & $-176.84(16)$ \\
$\mathrm{N}(1)-\mathrm{C}(1)-\mathrm{C}(3)-\mathrm{N}(2)$ & $5.70(17)$ \\
$\mathrm{C}(3)-\mathrm{N}(3)-\mathrm{C}(4)-\mathrm{O}(3)$ & $-3.6(2)$ \\
$\mathrm{C}(3)-\mathrm{N}(3)-\mathrm{C}(4)-\mathrm{N}(4)$ & $177.74(15)$ \\
\hline
\end{tabular}

Table 17: Antioxidant activity of EA1, AA2, and W3.

\begin{tabular}{lccc}
\hline Samples & $\begin{array}{c}\text { DPPH } \\
\text { radical } \\
\text { scavenging } \\
\text { activity } \\
\left(\mathrm{IC}_{50} \mu \mathrm{g} /\right. \\
\mathrm{mL})\end{array}$ & $\begin{array}{c}\text { Phosphomolybdenum } \\
\text { (mg.AAE/g of the } \\
\text { sample) }\end{array}$ & $\begin{array}{c}\text { FRAP (Fe(II) E/g } \\
\text { of the sample) }\end{array}$ \\
\hline EA1 & 23.17 & $709.17 \pm 1.51^{\mathrm{a}}$ & $23303.57 \pm 68.53^{\mathrm{b}}$ \\
AA2 & 159.23 & $72.87 \pm 0.99^{\mathrm{d}}$ & $7748.91 \pm 44.86^{\mathrm{c}}$ \\
W3 & 182.89 & $121.71 \pm 1.14^{\mathrm{c}}$ & $351.03 \pm 68.53^{\mathrm{d}}$ \\
BHT & 3.48 & $419.73 \pm 0.57^{\mathrm{b}}$ & $45169.83 \pm 118.23^{\mathrm{a}}$
\end{tabular}

EA1: essential oil; AA2: 4-(2-oxo-propyl)-cyclopentane-1,3-dione; W3: (2,5-dioxo-imidazolidin-4-yl)-urea or Allantoin; AAE: ascorbic acid equivalents; $\mathrm{Fe}(\mathrm{II}) \mathrm{E}$ : ferrous ion equivalents; values are mean of triplicate determination $(n=3) \pm$ standard deviation. Statistically significant at $p<0.05$, where $\mathrm{a}>\mathrm{b}>\mathrm{c}>\mathrm{d}$ in each row.

heptadecanol. These chemicals may act together to stabilize free radicals. In the case of single chemical therapeutic activity, the mechanism of the synergism was not investigated. As a result, the antioxidant potential of AA2 was shown to be much higher than that of W3. As a consequence, the findings imply that EA1 and AA2 may have therapeutic potential in combating the oxidative stress and pathology caused by $S$. morsitans envenomation.

In addition, fluorescence detection is a key method for determining the pharmacological action of (antivenom) substances [25]. The potential of the samples to quench the emission intensity of $S$. morsitans venom was shown by the linearity of the emission spectra [26]. The observed quenching might be ascribed to changes in venom protein secondary structure or denaturation, suggesting sample binding to S. morsitans venom protein $[27,28]$. The type and amount of the drug-venom protein interaction have a significant impact on the drug's pharmacological activity. The binding characteristics are helpful in determining a drug's pharmacological response and designing a dosing range $[29,30]$.

Scolopendra venom contains the aromatic amino acids tyrosine and tryptophan [31]. Tyrosine is found in venom at $15 \mathrm{~nm}$ and tryptophan at $60 \mathrm{~nm}$, according to the research. 


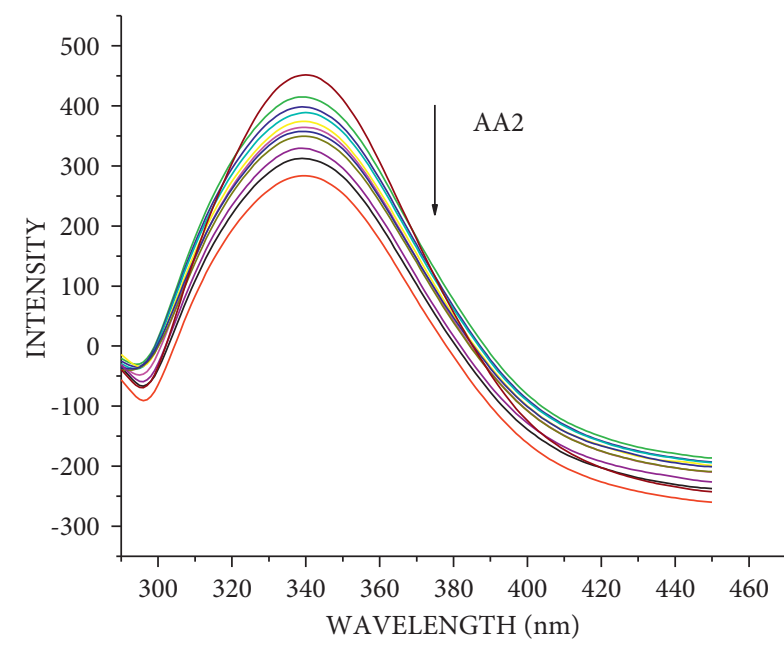

(a)

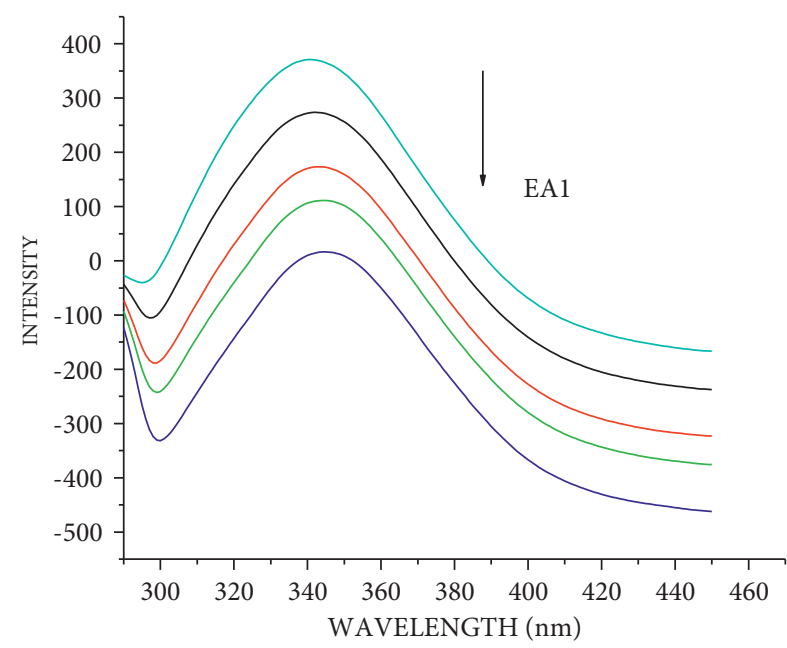

(b)

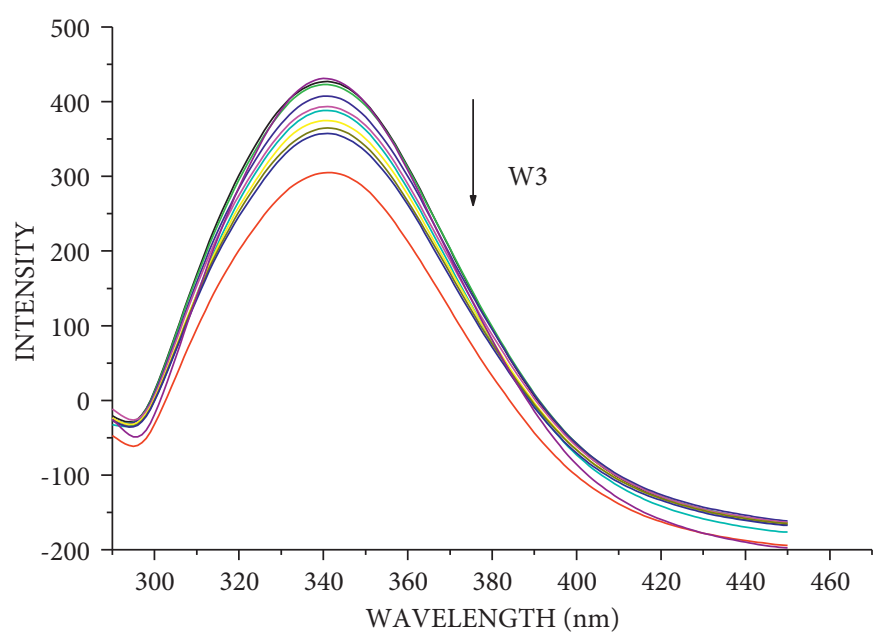

(c)

Figure 4: Emission spectra of venom in the presence of increasing concentration of EA1, AA2, and W3. The arrow shows the emission intensity changes upon increasing EA1, AA2, and W3 concentrations. (a) EA1 (an essential oil), (b) AA2 (4-(2-oxo-propyl)-cyclopentane1,3-dione), and (c) W3((2,5-dioxo-imidazolidin-4-yl)-urea or Allantoin).

The blue shift occurs when the AA2 and W3 are added, indicating an increase in hydrophobicity surrounding the fluorophore moiety. With a red shift in synchronous spectra, the EA1 revealed a reduction in emission intensity corresponding to tyrosine and tryptophan residues. In $S$. morsitans venom, red shift indicates an increase in hydrophilicity near the fluorophore [32-34]. The molecular environment in the region of the fluorophore moieties of $S$. morsitans venom was studied using synchronized fluorescence [35]. When comparing the quenching and binding constants, the antivenom activity of EA1, AA2, and
W3 was shown to be much higher than that of S. morsitans venom. Allantoin, an alkaloid derived from the A. radix, was shown to be effective against the haemorrhagic components found in the venoms of Naja naja atra and Bungarus multicinctus [36]. Allantoin was included to the national library of medicine and toxicology data network because it can be utilized as an antivenom [37]. Due to their greater quenching and binding constants, 4-(2-oxo-propyl)-cyclopentane-1,3-dione (AA2) and an essential oil (EA1) may be more potent antivenom agents than Allantoin (W3). 


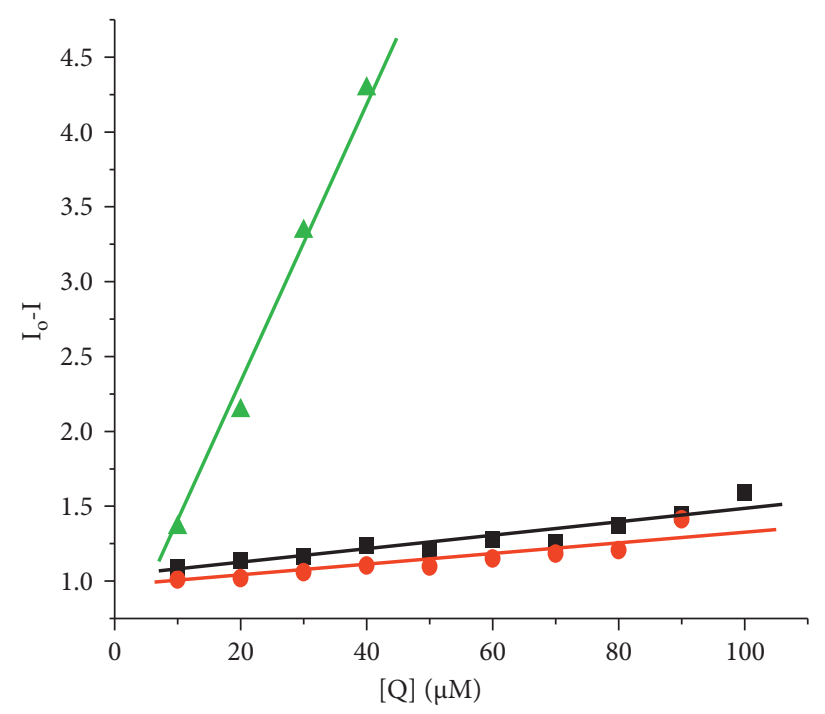

- $\mathrm{AA} 2$

- W3

$\triangle \mathrm{EA} 1$

Figure 5: Stern-Volmer plot of fluorescence titration of the EA1, AA2, and W3 with venom. (a) EA1 (an essential oil), (b) AA2 (4-(2-oxopropyl)-cyclopentane-1,3-dione), and (c) W3((2,5-dioxo-imidazolidin-4-yl)-urea or Allantoin).

TABLE 18: Quenching constant $\left(K_{\mathrm{sv}}\right)$, binding constant $\left(K_{\mathrm{bin}}\right)$, and the number of binding sites $(n)$ for the interaction of EA1, AA2, and W3 with venom.

\begin{tabular}{lccc}
\hline Compounds & Quenching constant $\left(K_{\mathrm{SV}} / \mathrm{M}^{-1}\right)$ & Binding constant $\left(K_{\mathrm{bin}} / \mathrm{M}^{-1}\right)$ & Number of binding sites $(n)$ \\
\hline EA1 & $9.99 \pm 0.123 \times 10^{5}$ & $9.52 \pm 0.08 \times 10^{6}$ & 1.479 \\
AA2 & $4.78 \pm 0.054 \times 10^{4}$ & $4.12 \pm 0.07 \times 10^{2}$ & 0.744 \\
W3 & $4.11 \pm 0.054 \times 10^{4}$ & $1.27 \pm 0.09 \times 10^{3}$ & 0.892 \\
\hline
\end{tabular}

(a) EA1 (an essential oil), (b) AA2 (4-(2-oxo-propyl)-cyclopentane-1,3-dione), and (c) W3 ((2,5-dioxo-imidazolidin-4-yl)-urea or Allantoin).

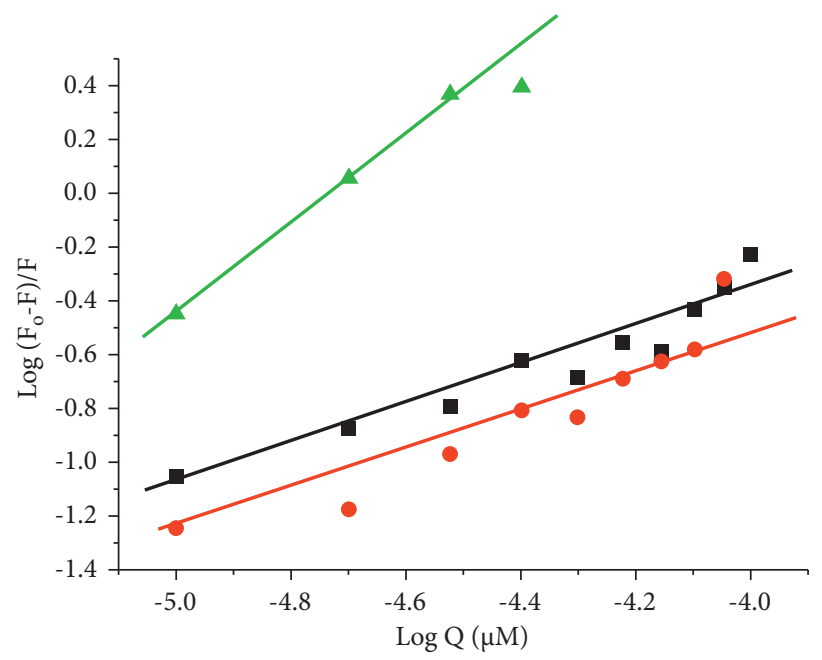

- AA2

- W3

$\triangle \mathrm{EA} 1$

FIGURE 6: Scatchard plot of fluorescence titration of the EA1, AA2, and W3 with venom. (a) EA1 (an essential oil), (b) AA2 (4-(2-oxopropyl)-cyclopentane-1,3,-dione), and (c) W3((2, 5-dioxo-imidazolidin-4-yl)-urea or Allantoin). 


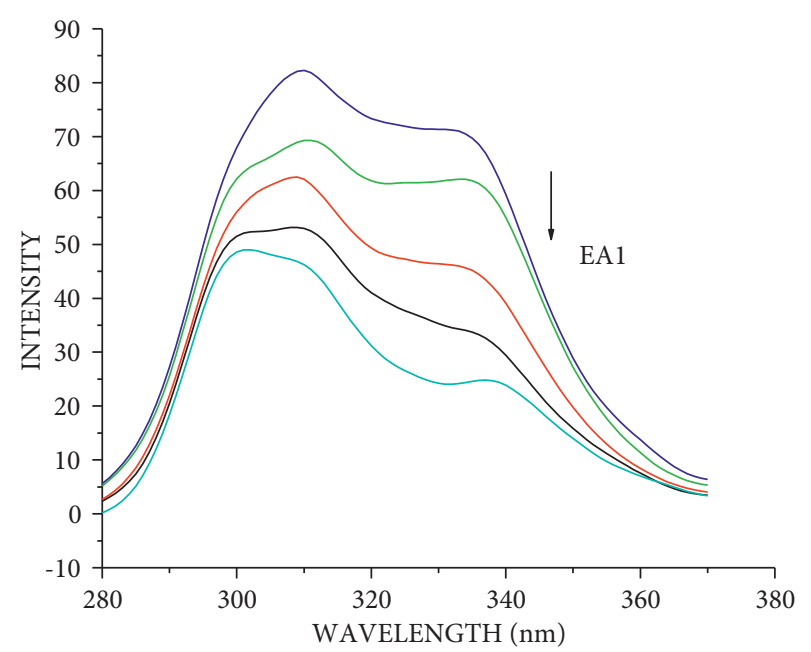

(a)

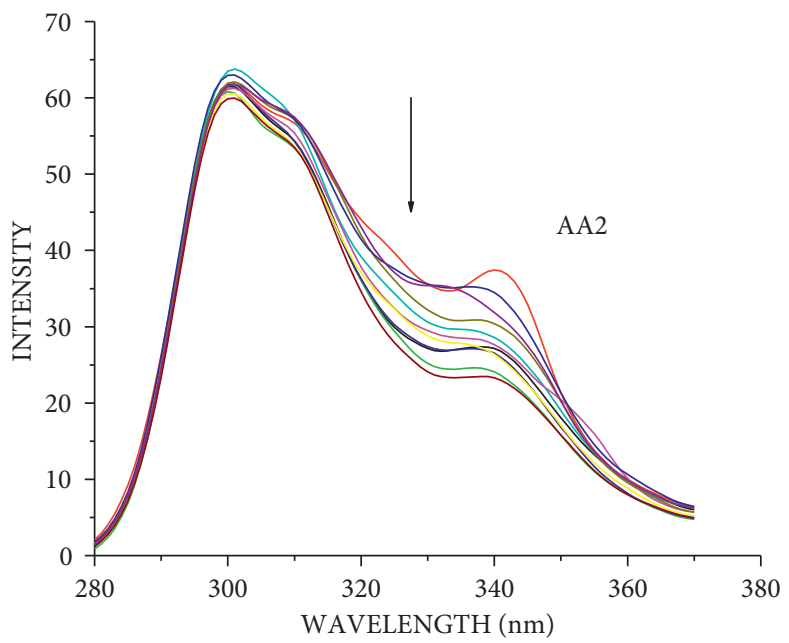

(b)

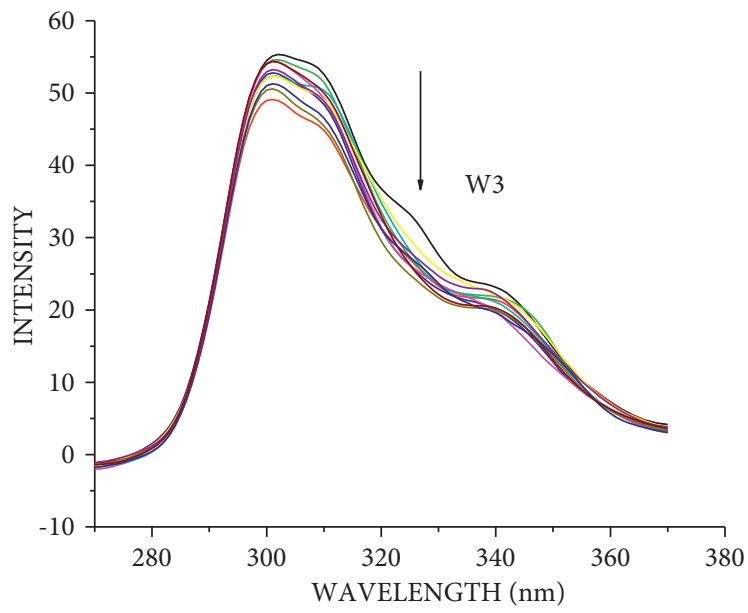

(c)

FIGURE 7: Synchronous spectra of venom in the presence of increasing concentration of EA1, AA2, and W3 for a wavelength difference of $\Delta \lambda=15 \mathrm{~nm}$. The arrow shows the emission intensity changes upon increasing concentration of EA1, AA2, and W3. (a) EA1 (essential oil), (b) AA2 (4-(2-oxo-propyl)-cyclopentane-1,3-dione), and (c) W3 ((2,5-dioxo-imidazolidin-4-yl)-urea or Allantoin).

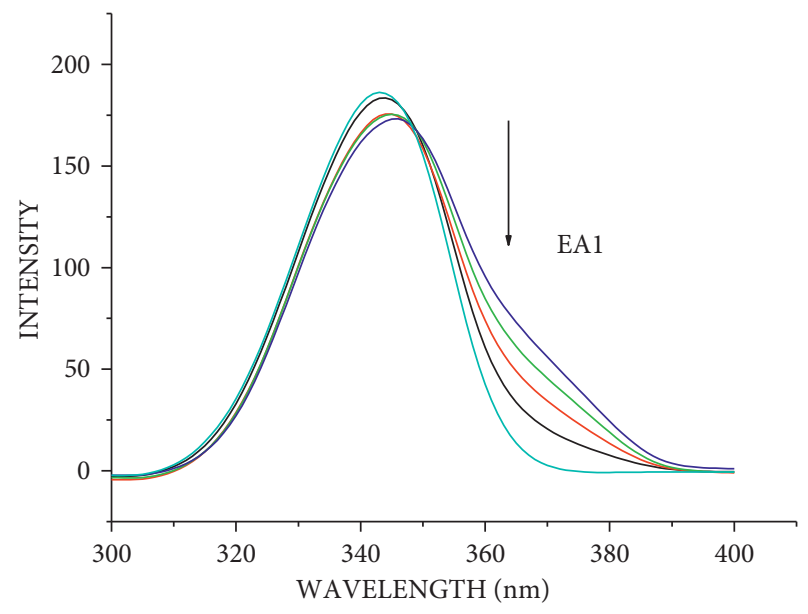

(a)

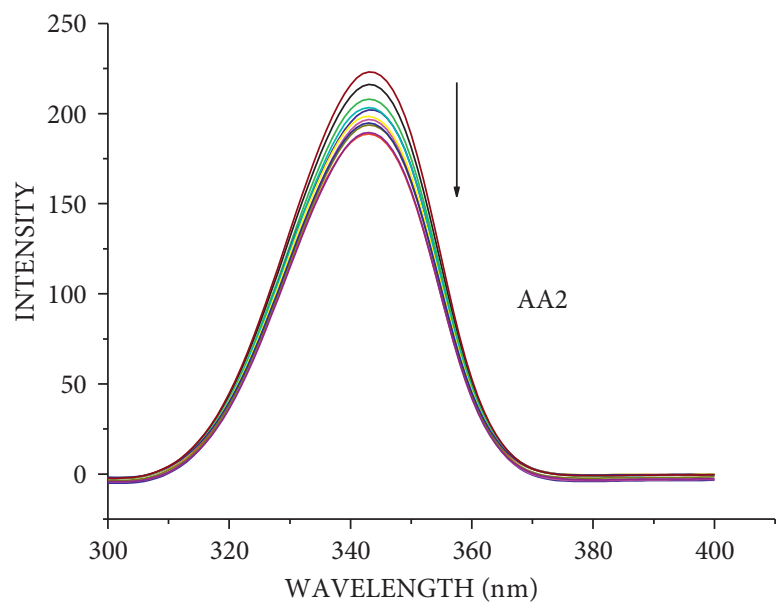

(b)

Figure 8: Continued. 


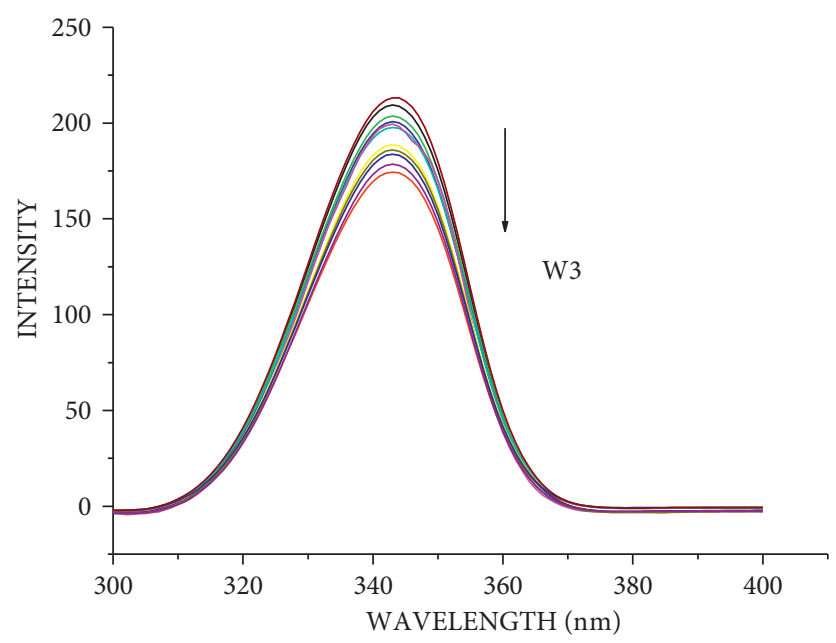

(c)

FIGURE 8: Synchronous spectra of venom in the presence of increasing concentration of EA1, AA2, and W3 for a wavelength difference of $\Delta \lambda=60 \mathrm{~nm}$. The arrow shows the emission intensity changes upon increasing concentration of EA1, AA2, and W3. (a) EA1 (essential oil), (b) AA2 (4-(2-oxo-propyl)-cyclopentane-1,3-dione), and (c) W3 ((2,5-dioxo-imidazolidin-4-yl)-urea or Allantoin).

\section{Conclusion}

Overall, the findings of this investigation backed with the conventional claim linked with $A$. indica and $P$. nigrum literature. It also aids in the promotion of medication usage in the present competitive pharmaceutical industry, which is rife with ineffective medicines. Further research into the interactions of isolated chemicals 4-(2oxo-propyl)-cyclopentane-1,3-dione, Allantoin, and EA1 with $S$. morsitans venom will aid in a better understanding of the venom neutralization process and the development of a green antivenom medication for human benefit.

\section{Abbreviations}

AV: $\quad$ Acid value

AA2: $\quad$ Compounds isolated $1 \%$ acetic acid in water

AAE: $\quad$ Ascorbic acid equivalents

BSI: $\quad$ Botanical survey of India

BHT: $\quad$ Butylated hydroxytoluene

CAIPN: Combination of Aristolochia indica L. and Piper nigrum L.

CCDC: $\quad$ Cambridge Crystallographic Data Centre

DPPH: 2,2-Diphenyl-1-picrylhydrazyl

EA1: Oil eluted from $40 \%$ ethyl acetate in methanol

FRAP: $\quad$ Ferric reducing antioxidant power

MECAIPN: Methanol extract of the polyherbal combination of Aristolochia indica L. and Piper nigrum L.

SV: $\quad$ Saponification value

TBI: $\quad$ Traumatic brain injury

TPTZ: $\quad$ 2,4,6-Tri(2-pyridyl)-s-triazine

W3: Compounds isolated from $100 \%$ water

ZSI: $\quad$ Zoological survey of India.

\section{Data Availability}

The data used to support the findings of this study are included in the article.

\section{Conflicts of Interest}

The authors declare that there are no conflicts of interest.

\section{Acknowledgments}

The authors acknowledge the funding support under UGCSAP (Ref No: F.5-16/2016/DRS-1 (SAP-II)), DST-FIST (Ref No: SR/FST/LS-II/2017/106 (C)), and MHRD and RUSA 2.0, BCTRC, and BEICH programs sanctioned to the Department of Botany, Bharathiar University. The authors also acknowledge the Vellore Institute of Technology, Vellore and Department of Physics and Nanotechnology, Bharathiar University, Tamil Nadu, for their assistance in crystal structure prediction. Furthermore, Karuppusamy Arunachalam acknowledges the CAS-PIFI (Chinese Academy of Sciences-President's International Fellowship for Postdoctoral Research, Reference no. 11682020PB0112) for his postdoctoral research.

\section{References}

[1] S. Dhivya, S. Saravanan, R. Murugan et al., "Evaluation of Aristolochiaindica L. and Piper nigrum L. methanol extract against centipede Scolopendramorsitans L. using wistar albino rats and screening of bioactive compounds by high pressure liquid chromatography: a polyherbal formulation," Biomedicine \& Pharmacotherapy, vol. 97, pp. 1603-1612, 2018.

[2] S. Parasuraman, G. S. Thing, and S. A. Dhanaraj, "Polyherbal formulation: concept of ayurveda," Pharmacognosy Reviews, vol. 8, no. 16, pp. 73-80, 2014. 
[3] L. Juliet and S. Sivakumar, "Standardization of poly herbal siddha medicine eladhichooranam," International Journal of Pharmaceutical Science Invention, vol. 4, pp. 33-37, 2015.

[4] R. R. Marandi and S. J. Britto, "Medicinal properties of edible weeds of crop fields and wild plants eaten by oraontribals of Latehar district, Jharkhand," Life Science, vol. 5, pp. 10-22, 2015.

[5] R. Rekka, S. Murugesh, and R. Prabakaran, "Ethnomedicinal study of plants used for the treatment of diabetetes and antidote for poisonous bite by malayali tribes of yercaud hills, southern eastern ghats, Salem district, Tamil Nadu," Life Science.Leaf, vol. 49, pp. 89-96, 2014.

[6] P. Vijaya, R. Ranjani, M. R. Rao, and G. Sudarsanam, "Identification of antidote medicinal plants against snake venom-a field survey," International Journal of Medicine and Pharmaceutical Sciences, vol. 3, pp. 21-32, 2013.

[7] Y. Kong, J. Hui, Y. Shao, S. Huang, H. Chen, and J.-F. Wei, "Cytotoxic and anticoagulant peptide from Scolopendra subspinipes mutilans venom," African Journal of Pharmacy and Pharmacology, vol. 7, no. 31, pp. 2238-2245, 2013.

[8] T. Parimelazhagan, Pharmacological Assays of Plant-Based Natural Products, Springer International Publishing, Cham, Switzerland, 2016.

[9] S. Sadasivam and A. Manickam, Biochemical Methods, New Age International (P) Limited, New Delhi, India, 2008.

[10] AOCS, American Oil Chemists' Society and Firestone, D. Official Methods and Recommended Practices of the American Oil Chemists' Society, AOCS Press, Urbana, IL, USA, 1994.

[11] H. Xu, X. Miao, and Q. Wu, "High quality biodiesel production from a microalga chlorella protothecoides by heterotrophic growth in fermenters," Journal of Biotechnology, vol. 126, no. 4, pp. 499-507, 2006.

[12] M. S. Demoz, K. P. Gachoki, K. J. Mungai, and B. G. Negusse, "GC-MS analysis of the essential oil and methanol extract of the seeds of steganotaenia araliacea hochst," American Journal of Plant Sciences, vol. 5, no. 26, pp. 3752-3760, 2014.

[13] R. Ashokkumar and M. Ramaswamy, "Phytochemical screening by FTIR spectroscopic analysis of leaf extracts of selected Indian medicinal plants," International journal of current microbiology and applied sciences, vol. 3, pp. 395-406, 2014.

[14] J. Martínez, L. A. Adrio, J. M. Antelo et al., "Cyclometallatedthiosemicarbazone palladium (II) compounds: the first crystal and molecular structures of mononuclear complexes with a $\eta$ 1-diphosphine ligand," Journal of Organometallic Chemistry, vol. 691, pp. 2721-2733, 2006.

[15] E. Ramachandran, S. P. Thomas, P. Poornima et al., "Evaluation of DNA binding, antioxidant and cytotoxic activity of mononuclear $\mathrm{Co}$ (III) complexes of 2-oxo-1,2-dihydrobenzo [h] quinoline-3-carbaldehyde thiosemicarbazones," European Journal of Medicinal Chemistry, vol. 50, pp. 405-415, 2012.

[16] J. Min, X. Meng-Xia, Z. Dong, L. Yuan, L. Xiao-Yu, and C. Xing, "Spectroscopic studies on the interaction of cinnamic acid and its hydroxyl derivatives with human serum albumin," Journal of Molecular Structure, vol. 692, no. 1-3, pp. 71-80, 2004.

[17] D. H. Kim, M. H. Park, Y. J. Choi et al., "Molecular study of dietary heptadecane for the anti-inflammatory modulation of NF-kB in the aged kidney," PLoS One, vol. 8, no. 3, Article ID e59316, 2013.

[18] V. Baud and M. Karin, "Is NF- $\kappa$ B a good target for cancer therapy? Hopes and pitfalls," Nature Reviews Drug Discovery, vol. 8, no. 1, pp. 33-40, 2009.

[19] R. Baskaran, P. M. Mohan, K. Sivakumar, and A. Kumar, "Antimicrobial activity and phylogenetic analysis of
Streptomyces parvulus Dosmb-d105 isolated from the mangrove sediments of Andaman Islands," Acta Microbiologica et Immunologica Hungarica, vol. 63, no. 1, pp. 27-46, 2016.

[20] I. Esteves, I. R. Souza, M. Rodrigues et al., "Gastric antiulcer and anti-inflammatory activities of the essential oil from Casearia sylvestris Sw," Journal of Ethnopharmacology, vol. 101, no. 1-3, pp. 191-196, 2005.

[21] V. Aparna, K. V. Dileep, P. K. Mandal, P. Karthe, C. Sadasivan, and M. Haridas, "Anti-inflammatory property of n-hexadecanoic acid: structural evidence and kinetic assessment," Chemical Biology \& Drug Design, vol. 80, no. 3, pp. 434-439, 2012.

[22] B. V. Raman, S. La, M. P. Saradhi et al., "Antibacterial, antioxidant activity and GC-MS analysis of Eupatorium odoratum," Asian Journal of Pharmaceutical and Clinical Research, vol. 5, pp. 99-106, 2012.

[23] “Allantoin online," 2018, https://pubchem.ncbi.nlm.nih.gov/ compound/Diazolidinylurea\#section=Patents.

[24] V. Chandra, J. Jasti, P. Kaur, A. Srinivasan, C. Betzel, and T. P. Singh, "Structural basis of phospholipase A2 inhibition for the synthesis of prostaglandins by the plant alkaloid aristolochic acid from a $1.7 \AA$ crystal structure,", Biochemistry, vol. 41, no. 36, pp. 10914-10919, 2002.

[25] S. Jager, L. Brand, and C. Eggeling, "New fluorescence techniques for high-throughput drug discovery," Current Pharmaceutical Biotechnology, vol. 4, no. 6, pp. 463-476, 2003.

[26] F. Dimiza, F. Perdih, V. Tangoulis, I. Turel, D. P. Kessissoglou, and G. Psomas, "Interaction of copper(II) with the nonsteroidal anti-inflammatory drugs naproxen and diclofenac: synthesis, structure, DNA- and albumin-binding," Journal of Inorganic Biochemistry, vol. 105, no. 3, pp. 476-489, 2011.

[27] Y.-Q. Wang, H.-M. Zhang, G.-C. Zhang, W.-H. Tao, and S.-H. Tang, "Interaction of the flavonoid hesperidin with bovine serum albumin: a fluorescence quenching study," Journal of Luminescence, vol. 126, no. 1, pp. 211-218, 2007.

[28] K. C. Oliveira, P. J. Spencer, R. S. Ferreira, and N. Nascimento, "New insights into the structural characteristics of irradiated crotamine," Journal of Venomous Animals and Toxins Including Tropical Diseases, vol. 21, no. 1, pp. 14-24, 2015.

[29] A. Rieutord, P. Bourget, G. Troche, and J. F. Zazzo, "In vitro study of the protein binding of fusidic acid: a contribution to the comprehension of its pharmacokinetic behaviour," International Journal of Pharmaceutics, vol. 119, no. 1, pp. 57-64, 1995.

[30] O. Borgå and B. Borgå, "Serum protein binding of nonsteroidal antiinflammatory drugs: a comparative study," Journal of Pharmacokinetics and Biopharmaceutics, vol. 25, pp. 63-77, 1997.

[31] B. M. Jarrar, "Histology and histochemistry of the venom apparatus of the centipede scolopendravalida lucas 1840 (chilopoda: scolopendromorpha Scolopendridae)," Tropical Zoology, vol. 23, pp. 107-115, 2010.

[32] C. Guozhen, H. Xianzhi, and Z. Zhuzi, Method of Fluorescence Analysis, Science Press, Beijing, China, 2nd edition, 1990.

[33] Y.-J. Hu, W. Li, Y. Liu, J.-X. Dong, and S.-S. Qu, "Fluorometric investigation of the interaction between methylene blue and human serum albumin," Journal of Pharmaceutical and Biomedical Analysis, vol. 39, no. 3-4, pp. 740-745, 2005.

[34] R. Kumar, Í. P. Caruso, A. Ullah et al., "Exploring the binding mechanism of flavonoid quercetin to phospholipase A2: fluorescence spectroscopy and computational approach," $E$ uropean Journal of Experimental Biology, vol. 7, pp. 33-44, 2017.

[35] N. Wang, L. Ye, B. Q. Zhao, and J. X. Yu, "Spectroscopic studies on the interaction of efonidipine with bovine serum 
albumin," Brazilian Journal of Medical and Biological Research, vol. 41, no. 7, pp. 589-595, 2008.

[36] L. H. Tsai, L. L. Yang, and C. Chen, "Inactivation of Formosan snake venoma in vivo by ariatolochic acid," Formosan Science, vol. 34, p. 40, 1980.

[37] P. L. Currance, B. Clements, and A. C. Bronstein, Emergency Care For Hazardous Materials Exposure, Elsevier Mosby, St. Louis, MO, USA, 3rd edition, 2005. 